\title{
A White Paper on Global Wheat Health Based on Scenario Development and Analysis
}

\author{
S. Savary, ${ }^{\dagger}$ A. Djurle, J. Yuen, A. Ficke, V. Rossi, P. D. Esker, J. M. C. Fernandes, E. M. Del Ponte, J. Kumar, L. V. Madden, \\ P. Paul, N. McRoberts, P. K. Singh, L. Huber, C. Pope de Vallavielle, S. Saint-Jean, and L. Willocquet
}

First and seventeenth authors: AGIR, Université de Toulouse, INRA, INPT, INP-EI PURPAN, Castanet-Tolosan, France; second and third authors: Department of Forest Mycology and Plant Pathology, Swedish University of Agricultural Sciences, Uppsala, Sweden; fourth author: NIBIO, Plant Health and Plant Protection Division, N-1430 As, Norway; fifth author: Istituto di Entomologia e Patologia Vegetale, Università Cattolica del Sacro Cuore, Piacenza, Italy; sixth author: Center for Research in Plant Protection, School of Agronomy, University of Costa Rica, San Pedro Montes de Oca, Costa Rica; seventh author: Embrapa Trigo, Passo Fundo, RS, Brazil; eighth author: Departamento de Fitopatologia, Universidade Federal de Viçosa, Viçosa, MG, Brazil; ninth author: G. B. Pant University of Agriculture \& Technology, Pantnagar, Uttaranchal, India; tenth and eleventh author: Department of Plant Pathology, Ohio State University, Wooster 44691; twelfth author: Department of Plant Pathology, University of California, Davis, CA; thirteenth author: International Maize and Wheat Improvement Center (CIMMYT), Apdo. Postal 6-641, 06600 Mexico D.F., Mexico; fourteenth and sixteenth authors: EcoSys, INRA, AgroParisTech, University of Paris-Saclay, Thiverval-Grignon, France; and fifteenth author: Bioger, INRA, AgroParisTech, Univ Paris-Saclay, Thiverval-Grignon, France.

Accepted for publication 15 June 2017.

\begin{abstract}
Scenario analysis constitutes a useful approach to synthesize knowledge and derive hypotheses in the case of complex systems that are documented with mainly qualitative or very diverse information. In this article, a framework for scenario analysis is designed and then, applied to global wheat health within a timeframe from today to 2050. Scenario analysis entails the choice of settings, the definition of scenarios of change, and the analysis of outcomes of these scenarios in the chosen settings. Three idealized agrosystems, representing a large fraction of the global diversity of wheat-based agrosystems, are considered, which represent the settings of the analysis. Several components of global changes are considered in their consequences on global wheat health: climate change and climate variability, nitrogen fertilizer use, tillage, crop rotation, pesticide use, and the deployment of host plant resistances. Each idealized agrosystem is associated with a scenario of change that considers first, a production situation and its dynamics, and second, the impacts of the evolving production situation on the evolution of crop health. Crop health is represented by six functional

groups of wheat pathogens: the pathogens associated with Fusarium head blight; biotrophic fungi, Septoria-like fungi, necrotrophic fungi, soilborne pathogens, and insect-transmitted viruses. The analysis of scenario outcomes is conducted along a risk-analytical pattern, which involves risk probabilities represented by categorized probability levels of disease epidemics, and risk magnitudes represented by categorized levels of crop losses resulting from these levels of epidemics within each production situation. The results from this scenario analysis suggest an overall increase of risk probabilities and magnitudes in the three idealized agrosystems. Changes in risk probability or magnitude however vary with the agrosystem and the functional groups of pathogens. We discuss the effects of global changes on the six functional groups, in terms of their epidemiology and of the crop losses they cause. Scenario analysis enables qualitative analysis of complex systems, such as plant pathosystems that are evolving in response to global changes, including climate change and technology shifts. It also provides a useful framework for quantitative simulation modeling analysis for plant disease epidemiology.
\end{abstract}

Plant disease epidemiology generates very diverse information linking the dynamics of plant diseases with the physical environment, the genetic variation and variability of pathogens, the genetic makeup and diversity of plant populations, the organization of landscapes, or the management of plant populations as a result of decisions of different types. Many of the important questions faced by plant disease epidemiology delve on the consideration of multiple processes, involving several epidemiological components, which are under the influence of several factors. Given the complexity of the systems which epidemiological analyses address, a range of advanced statistical and modeling techniques are in routine use. Among the approaches to synthesize information, notable for instance are the methods of statistical meta-analysis, which enable to assemble multiple data sets pertaining to the same question, and derive overall conclusions (Paul et al. 2005). Simulation modeling constitutes another type of approach, which may be considered when knowledge on processes, along with quantitative measurements, are available to both parameterize and evaluate a model that

${ }^{\dagger}$ Corresponding author: S. Savary; E-mail: serge.savary@toulouse.inra.fr

(C) 2017 The American Phytopathological Society sums-up key hypotheses on the functioning of the considered disease system (Rabbinge and De Wit 1989; Savary et al. 2006).

On the other hand, when the system under consideration is very complex and diverse, when a large fraction of the information is qualitative, and when future projections involve many uncertainties, scenario analysis (Öborn et al. 2013; Sundström et al. 2014) constitutes an interesting approach to synthesize knowledge, identify knowledge gaps, and derive hypotheses. Scenario analyses allow projection of dynamic processes under a range of combined hypotheses (collectively called "scenarios"). For example, the Millennium Ecosystem Assessment conducts a global analysis along four scenarios, which were set according to (i) global development paths (globalization and regionalization), and (ii) approaches to ecosystem management (reactive and proactive policies; Millennium Ecosystem Assessment 2005). More recently, the Agrimonde analysis (Paillard et al. 2014) involved two contrasting scenarios, addressing agriculture and food security in 2050: Agrimonde 1, a scenario of sustainable food and agricultural development, and Agrimonde GO, a scenario of global markets and major technological progress. Scenario analyses are also key components in projects such as the Agriculture Modeling Intercomparison Project (AGMiP), whereby scenarios are developed according to both climate change and socio-economic considerations (Rosenzweig and Hillel 2015, page 970). Scenario analysis was introduced in the field of plant health 
(Rabbinge and Van Oijen 1997) but has seldom been used in plant disease epidemiology. One objective of this article is to apply this approach and explore its potential.

The effects of global change on crop diseases constitute one such complex problem. Many studies have addressed the impacts of global change, especially climate change (IPCC 2014), on food production (Rosenzweig and Parry 1994), including wheat production (Ortiz et al. 2008). Many reports on the effects of climate change on agriculture do not consider plant health. Several reviews have addressed the relationships between global and climate changes, plant pathogens, and plant diseases (Chakraborty and Newton 2011; Garrett et al. 2011). These have mainly focused on the direct effects of climate change and climate variability on plant pathogens, sometimes with an emphasis on specific biological processes associated with a few components of climate change. Plant diseases are exposed to the direct effects of climate change, but also to the multiple indirect effects of climate change, through a cascade of processes that affect crop stands, cultivated fields, farms, and production situations (Savary et al. 2011). This is because plant diseases are integral parts of complex systems involving pathogens, host plant populations, and their environment, along with human beings and societies (Zadoks and Schein 1979, page 320). A systems perspective, with distinct levels of hierarchy (Rabbinge and De Wit 1989), may enable addressing such systems.

We chose to conduct the present analysis on wheat for a number of reasons. Wheat is a key staple crop which plays a major role in global food security. Current threats, and concerns for the future, have motivated many studies to analyze wheat production systems, how yields can be increased (what factors hamper current yields), and what are the trends which can be expected in terms of wheat production in the future, according to global change scenarios, including climate change (Brisson et al. 2010; Lobell et al. 2011; Ortiz et al. 2008). Such studies are critical for priority-setting, and to inform strategic decisions for policy designing. These studies however ignore the effects of plant diseases on wheat performances. Yet, the wheat production systems worldwide have been encountering the (re) emergence of diseases such as stem rust, stripe rust, wheat blast, and Fusarium head blight (FHB) over the two last decades (Singh et al. 2016). The causes of these changes in disease patterns are associated with a range of factors, which we examine here. Identifying, quantifying, and hierarchizing the causes of these changes may not be possible, but predicting the risks associated with such changes according to the epidemiological features of the considered diseases may provide a robust approach. This type of analysis was for example developed to predict risk levels associated with host plant resistance breakdown (McDonald and Linde 2002).

The objectives of the work reported here were, first, to design a framework for a scenario analysis addressing global crop health and its possible evolution with global changes, including climate change, and second, to implement this approach in the case of wheat health. In order to achieve this, a limited set of idealized agrosystems were considered and were allowed to evolve along preset storylines generated by multiple drivers of agricultural change.

\section{ANALYTICAL FRAMEWORK}

We follow the approach of Sundström et al. (2014) and of Rabbinge and Van Oijen (1997), with slight modifications inspired from a report from the World Health Organization (2013) and previous analyses (Chakraborty et al. 2000; Duveiller et al. 2007; Garrett et al. 2011; Savary et al. 2011). We consider a timeframe from today to 2050, with three agricultural settings representing idealized wheat-based agrosystems in the world. Baseline scenarios are defined for each of these settings, along with a series of drivers of changes operating within the considered timeframe. These drivers of change are then allowed to influence the three settings, in particular from the standpoint of crop health, which we define below. This leads to a derivation of the elements required for a risk analysis, whereby risk probability and risk magnitude (respectively termed "probability" and "impact" in Sundström et al. 2014), are addressed in a qualitative, categorical manner.

Definitions. We use the following three definitions in the present analysis.

- An agrosystem refers to a set of attributes-biological (e.g., species richness and diversity), agronomical (e.g., productivity, nutrient cycling, standing biomass, and production biomass), and economical (e.g., gross margin and returns on labor)—that characterize agricultural production units such as farms (Dalsgaard and Oficial 1997). Each attribute of a given agrosystem varies within a bounded range of settings.

- A production situation is the combination of environmental, social, and economical factors where agriculture takes place (Breman and De Wit 1983; Rabbinge and De Wit 1989). Defining the considered production situation is instrumental to address levels of systems productivity (Savary et al. 2006; Van Ittersum and Rabbinge 1997). An agrosystem encompasses a series of production situations where each production situation corresponds to a sample taken from the vector of multiple attributes that characterize an agrosystem.

- Crop health is viewed as the pattern of multiple diseases that may occur in a cultivated plant stand in a production situation (Savary et al. 2017).

Steps of the analysis. Our analysis proceeds in four steps, which are summarized in Figure 1.

- A first step is to summarize the changes that may be expected to occur in production situations prevailing in the three idealized wheat-based agrosystems considered in the analysis. Drivers of change affect components of production situations. We outline the changes in the components of production situation which are exposed to these drivers, leading to the evolution of these agrosystems. To that aim, we consider three contrasting wheat-based agrosystems.

- In a second step, we define functional groups of pathogens associated with wheat diseases. This is done by grouping wheat diseases on the basis of their ecological and epidemiological characteristics, and on the damage mechanisms with which they are associated.

- In the third step, we develop a broad framework that describes the ecological and epidemiological responses of the wheat disease groups to shifts of the production situation components considered in the wheat-based agrosystem.

- In the fourth step, we combine the results of the previous steps to generate a risk analysis of the effects of global change, including climate change, on wheat diseases.

Agricultural settings: Selecting three agrosystems and the associated production situations. Wheat cultivation takes place over an extremely wide diversity of production situations, i.e., of ecological, social, and economical settings (Shiferaw et al. 2013). We chose to define three idealized, generic wheat-based agrosystems (Fig. 2), which capture a large fraction of this global diversity, and which contribute to differing degrees, and in different ways, to food security in the world (FAO 2016). A first criterion for selecting an agrosystem is based on the associated production situations. The concept of production situation has been operationalized (Savary et al. 1996, 2006; Savary and Zadoks 1992) to characterize components of crop health, to understand crop health variability, and to assess strategies for crop health management in several crops, including rice (Savary et al. 2000; Willocquet et al. 2004), wheat (Willocquet et al. 2008), or coffee (Avelino et al. 2004). We define the three agrosystems as follows.

- Agrosystem 1: small ( $10^{1}$ to $10^{2}$ ha) farms, intensive agriculture, average to good agricultural infrastructures (supply, markets), average to good access to information, heavy chemical fertilizer (especially $\mathrm{N}$ ) inputs, heavy reliance on synthetic pesticides, generally good access to improved, disease-resistant wheat 
varieties. The average actual wheat yields of Agrosystem 1 are high: 7 to $8.9 \mathrm{t} \mathrm{ha}^{-1}$ (FAO 2016). Examples: Western and Southern Europe, Eastern United States, North-East China. Agrosystem 1 contributes to the major exporting role of countries (FAO 2016) such as the United States, France, and Western Europe.

- Agrosystem 2: large farms ( $10^{2}$ to $\left.10^{3} \mathrm{ha}\right)$, extensive agriculture, good agricultural infrastructures, excellent access to information, limited soil cultivation, no to limited chemical fertilizer inputs, limited use of synthetic pesticides, full access to improved, disease-resistant wheat varieties. The average actual wheat yields of Agrosystem 2 are variable: 1.8 to $3.6 \mathrm{t} \mathrm{ha}^{-1}$ (FAO 2016). Examples: Canada, Brazil (e.g., Parana), U.S. Midwest. Agrosystem 2 is the main production engine of exporting countries such as the United States, Canada, and Australia (FAO 2016).

- Agrosystem 3: farms of very variable size (100 to $\left.10^{2} \mathrm{ha}\right)$, but often small, semiarid, rain-fed, wheat cultivation often associated with grazing animals (rangeland), low inputs (chemical, in general, fertilizer in particular), very little synthetic pesticides, poor access to information, use of disease-resistant varieties when available. The average actual wheat yields of Agrosystem 3 are moderate and variable: 2 to $5 \mathrm{t} \mathrm{ha}^{-1}$ (FAO 2016). Examples: Central Asia, the Indo-Gangetic Plains of South Asia, South-Central China, Middle East, North Africa. Agrosystem 3 constitutes the breadbasket of major wheat producers, such as China, India, and of countries of Central Asia, the Middle East, and North Africa (Shiferaw et al. 2013; FAO 2016).

There is large variation about these three idealized settings in a given region of the world. However, our focus concerns the general characteristics of these agrosystems and their evolution.

Scenarios of change in three wheat-based agrosystems. We consider evolution of the three agrosystems within an overall dynamic in the 2010 to 2050 timeframe, where a series of drivers of change operate (Fig. 3): (i) the world population increases from 7 to close to 10 billion (United Nations 2016); (ii) climate change leads to increases in mean global temperatures, especially daily minimum temperatures (Easterling et al. 1997), and to irregular rainfall distribution with increased frequency of extreme rain events; (iii) conservation agriculture (Hobbs 2007; Hobbs et al. 2008; Turmel et al. 2015) becomes more frequent in environments where it is best adapted and necessary to conserve soils and natural resources; (iv) chemical fertilizer inputs decline, in response to concerns about fertilizer (and energy) input productivity, in environments where they are heavily used; and (v) synthetic pesticide use declines in production situations where they are heavily applied, reflecting concerns about pesticide use, combined with build-up of pesticide resistances in pathogen populations and a reduced rate of new products development. These overall trends translate into different patterns of changes in the three agrosystems, which we summarize in the distinct evolution scenarios (Öborn et al. 2013; Rabbinge and Van Oijen 1997) of Figure 3, and which we display in a fashion similar to that of the Millenium Ecosystem Assessment (Cassman and Wood 2005; Millennium Ecosystem Assessment 2005).

Agrosystem 1 currently enjoys a very favorable climate for wheat cultivation. Climate change will lead to more frequent rainy spells and droughts, without however making climate unfavorable in this agrosystem (IPCC 2014). Importantly, one may assume that winters will become milder, and summers, at least in some cases, rainier (Ciscar et al. 2014; IPCC 2014). We also assume that conservation agriculture becomes more frequent over the period. Chemical fertilizer use remains high, but measurably declines to avoid overuse and reduce negative environmental impacts. This agrosystem, which today relies strongly on synthetic pesticides, will progressively make use of host plant resistances (HPRs) in a more consistent way, with HPR genes rotated over time and strategically deployed over space. While climate change is assumed to have comparatively limited impact on Agrosystem 1, this agrosystem is also part of a dense and sophisticated social and economic fabric where the impacts of population growth are comparatively limited. As a result, agricultural labor availability, albeit limited, will persist, enabling a reasonably good monitoring of crops and careful crop husbandry.

Agrosystem 2 strongly contributes to global wheat surpluses and international trade (FAO 2016). Fewer chemical inputs (mineral fertilizer and synthetic pesticides) are involved in Agrosystem 2 compared with Agrosystem 1. Because of increasing global demand for wheat, and also because of increasing crop health problems which we discuss below, this system alters its mode of production toward increased chemical fertilizer and synthetic pesticide inputs. Conservation agriculture remains dominant in this system which is designed for environments where agricultural water is often a main limitation, and where labor is extremely scarce. Agrosystem 2 is strongly exposed to the effects of climate change (IPCC 2014), including frequent and severe drought.

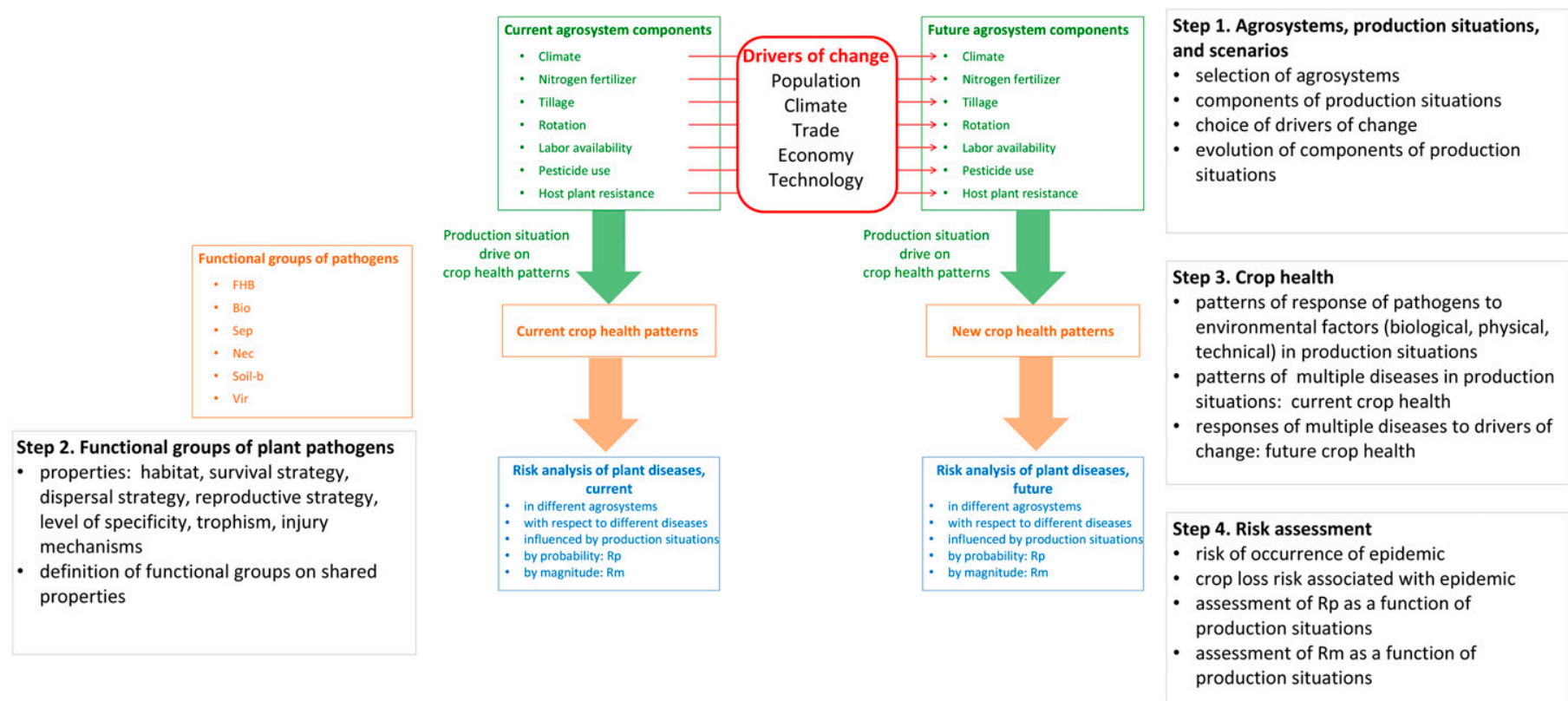

Fig. 1. Steps taken in the definition and assessment of crop health in differing agrosystems influenced by global, including climate, changes. 
Agrosystem 3 is adapted to climatic conditions that are marginally favorable for wheat cultivation. This is compensated by comparatively much higher agricultural labor availability and well-adapted technologies, including crop husbandry and germplasm. Because of the food demand that population growth generates locally or regionally, Agrosystem 3 expands in areas where conservation agriculture may dominate. This setting is very strongly exposed to climate change, with high risks of drought and heat waves (IPCC 2014). Chemical inputs nevertheless increase slightly, especially in the form of mineral fertilizers. Host plant resistances remain the main instrument of disease control.
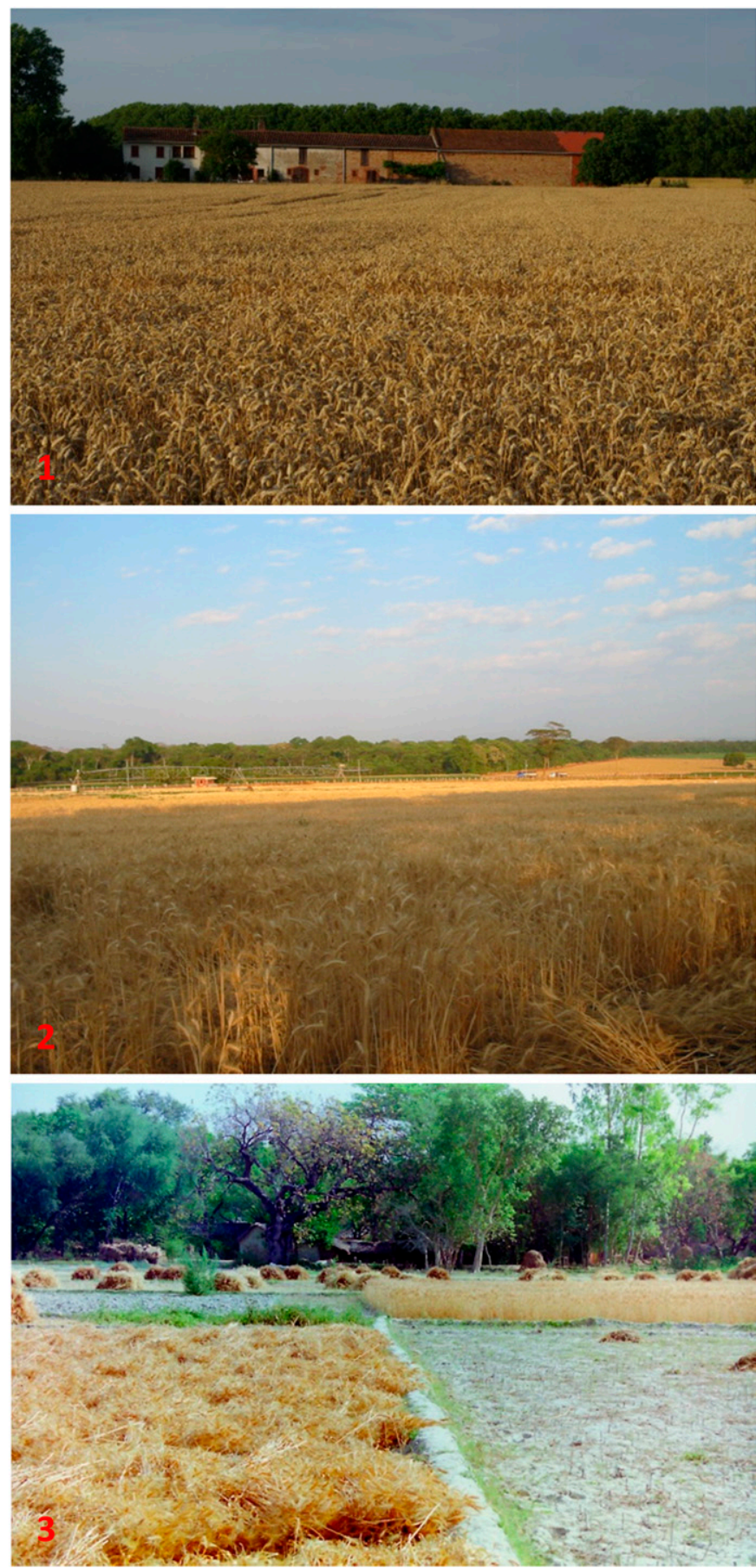

Fig. 2. Illustrations for three wheat-based agrosystems. Agrosystem 1 (top): small intensive farm, temperate agriculture; Agrosystem 2: extensive large farm; and Agrosystem 3 (bottom): semiarid or transition climate farm.
Functional groups of wheat pathogens. The range of wheat pathogens is very wide, from viruses to fungi, and from soilinhabiting organisms to long-range aerially dispersed pathogens. We developed a typology of these pathogens and of the associated diseases on the basis of (i) their ecological and epidemiological characteristics, including dispersal and survival mechanisms, and (ii) the damage mechanisms associated with diseases (Table 1).

A first functional group of wheat pathogens consists of organisms causing FHB. This group is fairly homogeneously composed of similar fungi. Fusarium spp. are able to infect a relatively wide range of hosts, including small grains. These fungi are saprotrophs and therefore able to survive on crop residues. An important feature of FHB epidemics is that the amount of primary inoculum produced, which can be very large, is dispersed aerially over short to large distance at the landscape scale, and is responsible for wheat ear infection at or about the flowering stage (Keller et al. 2014; McMullen et al. 2012; Paul et al. 2005). Ear infection is often multispecific, and research today addresses a complex of pathogens rather than a unique species (Bottalico and Perrone 2002; Del Ponte et al. 2015; Siou et al. 2014). Loss of grain dry matter caused by the disease can be high, but is frequently moderate. However, yield loss is compounded by the production of several different toxins with variable toxicity on human and animal health (trichothecenes, zearalenone, moniliformin, fumonisins, and the enniatins; Nielsen et al. 2011; Van Der Fels-Klerx et al. 2012).

The biotrophic fungi (Bio) group is very heterogeneous taxonomically (Table 1). This group includes pathogens (i) that develop highly specific and sophisticated interactions with their host, (ii) with intimate genetic association with the host plant, (iii) resulting in strong evolutionary capability, (iv) with a very rapid life cycle, (v) that proceeds through the production of very large amounts of propagules, which (vi) can be dispersed over very large, sometimes continental, distances (Brown and Hovmøller 2002). Diseases caused by these pathogens often result in heavy quantitative yield losses primarily resulting from the diversion of carbohydrates from photosynthetically active tissues to pathogen growth and propagule multiplication (Ayres 1981). The strict trophic requirements of pathogens of this group governs their survival in the absence of the cultivated host crop, on alternate hosts or on sometimes geographically distant cultivated hosts.

Organisms of the Septoria (Sep) group (none of which are still classified in the genus Septoria today) are hemibiotrophic, with weaker host specialization (Table 1). Sep pathogens are able to survive on crop residues, enabling strong initial infections of cultivated crops from nearby sources of inoculum (Suffert et al. 2011). Asexual propagules are produced in fairly large numbers and often dispersed through rain and wind and rain-splash over relatively short distances (Brennan et al. 1985). Ascospores are wind dispersed over longer distances and may be an important source of inoculum for early infections in the autumn (Eriksen and Munk 2003; Sommerhalder et al. 2010). Heavy yield losses may be derived from lesion development on green tissues, reducing the light interception by photosynthetically active tissue and accelerating tissue senescence (Bockus et al. 2010).

The necrotrophic fungi ( $\mathrm{Nec}$ ) group is taxonomically more diverse (Table 1). Pathogens of this group have strong saprophytic capabilities, enabling them to develop large inoculum bases in crop residues and soil. The associated diseases in this group cause a range of symptoms, from leaf lesions to rapidly expanding necrotic lesions on stems and stem bases. These result in reduced light interception, accelerated tissue senescence, as well as tiller/plant death, and thus stand reduction (Willocquet et al. 2008). The resulting diseases have been associated with physiologically weakened hosts resulting from drought, heat, or poor nutrition (Duveiller and Dubin 2002; Gurung et al. 2012). This association with unfavorable crop environment partly results from a lack of research emphasis on these diseases, which nevertheless can be the cause of heavy yield losses (Gurung et al. 2012).

The group for root and stem base pathogens (Table 1, Soil-b) is, again, taxonomically very heterogeneous, including fungal and 
fungal-like organisms, and viruses. The pathogens considered in this group are soil-inhabiting organisms. Their levels of host specialization are extremely variable (Bockus et al. 2010), from narrow (Soilborne cereal mosaic virus, SBVMV, and Soilborne wheat mosaic virus, SBWMV), to moderate (O. yallundae), to wide ( $R$. cerealis). These pathogens cause localized to systemic lesions, especially on plant root systems and stem bases, leading to disruption of water and nutrient transport, but also of photosynthesis systems (viruses), and stand reduction. They have various survival strategies in soils (Bockus et al. 2010; Raaijmakers et al. 2009), some being strong saprotrophs ( $R$. cerealis), others being poor competitors of the soil flora and surviving only on plant residues ( $G$. graminis), and other again surviving only in the tissue of fungal-like organisms which are their vectors (SBCMV, SBWMV; Kühne 2009). As many soilborne organisms, the life strategies of these pathogens are based on an equilibrium between a large primary inoculum base and a limited dispersal ability (Gosme et al. 2007; Raaijmakers et al. 2009).

The last functional group of Table 1, viruses (Vir), refers to viruses that are transmitted by flying insects. The ideotype disease of this group is BYDV, representing the complex of viral species of the family Luteoviridae causing barley yellow dwarf symptoms in the family Poaceae (Bockus et al. 2010). The viruses of this group are diverse, but are specialized with respect to their vectors (Bockus et al. 2010), they also share the same damage mechanism, a reduction of radiation use efficiency of the infected host plant (Boote et al. 1983; Savary and Willocquet 2014). Pathogens of this group share similar dispersal strategies with their ability for dispersal over large distance owing to their transportation by insect vectors. Large quantities of inoculum may be transported across the field and the landscape scales, enabling infection of healthy stands (Thresh 1978, 1982).

Disease risk probability and magnitude, and their categorization. We use a risk-analytical framework (Rowe 1980; Sundström et al. 2014) to characterize the importance of wheat diseases, where risk is decomposed into two terms. The first is risk probability, which we translate into the probability of an epidemic occurring. The other is risk magnitude, which we convert into crop loss, that is, into the amount of quantitative or qualitative loss that a disease epidemic can cause when it occurs. In addition to reduction of crop yield, this latter definition for risk magnitude incorporates disease effects such as a reduction of the quality of the harvested crop (e.g., milling quality), as well as the accumulation of mycotoxins.

Disease risks (probability and magnitude) of the six disease groups are expected to vary in both their current levels and in their evolutions

\begin{tabular}{|c|c|c|c|}
\hline & $\begin{array}{l}\text { Agrosystem } 1 \\
\text { Small intensive farm, } \\
\text { temperate agriculture }\end{array}$ & $\begin{array}{l}\text { Agrosystem } 2 \\
\text { Extensive large farm }\end{array}$ & $\begin{array}{l}\text { Agrosystem } 3 \\
\text { Semi-arid or transition } \\
\text { climate farm }\end{array}$ \\
\hline $\begin{array}{l}\text { Current climate } \\
\text { and } \\
\text { future climate } \\
\text { variability }\end{array}$ & $\begin{array}{l}\text { Current: very favourable } \\
\text { climate } \\
\text { Future: moderate } \\
\text { droughts and rainy } \\
\text { events; mean } \\
\text { temperature increases }\end{array}$ & $\begin{array}{l}\text { Current: favourable } \\
\text { climate } \\
\text { Future: moderate } \\
\text { droughts and rainy } \\
\text { events; mean } \\
\text { temperature increases }\end{array}$ & $\begin{array}{l}\text { Current: marginal } \\
\text { climate } \\
\text { Future: severe } \\
\text { droughts, floods, } \\
\text { heat waves }\end{array}$ \\
\hline $\begin{array}{l}\text { Current fertilizer } \\
(\mathrm{N}) \text { inputs and } \\
\text { future fertilizer } \\
\text { inputs }\end{array}$ & $\begin{array}{l}\text { Current: high to very high } \\
\text { Future: slight decrease } \\
\text { (improvement) of } \\
\text { inputs }\end{array}$ & $\begin{array}{l}\text { Current: nil to low } \\
\text { Future: slight increase } \\
\quad \text { (improvement) of } \\
\text { inputs }\end{array}$ & $\begin{array}{l}\text { Current: low fertilizer } \\
\text { inputs } \\
\text { Future: slight increase } \\
\text { (improvement) of } \\
\text { inputs }\end{array}$ \\
\hline $\begin{array}{l}\text { Current tillage } \\
\text { and } \\
\text { future tillage } \\
\text { practices }\end{array}$ & $\begin{array}{l}\text { Current: conventional } \\
\text { tillage dominant } \\
\text { Future: conservation } \\
\text { agricuiture becoming } \\
\text { more frequent }\end{array}$ & $\begin{array}{l}\text { Current: conservation } \\
\text { agriculture frequent } \\
\text { Future: conservation } \\
\text { agriculture becomes } \\
\text { dominant }\end{array}$ & $\begin{array}{l}\text { Current: conventional } \\
\text { tillage dominant } \\
\text { Future: increase of } \\
\text { conservation } \\
\text { agriculture }\end{array}$ \\
\hline $\begin{array}{l}\text { Current rotations } \\
\text { and } \\
\text { future rotation } \\
\text { practices }\end{array}$ & $\begin{array}{l}\text { Current: diverse rotation } \\
\text { Future: diversity of } \\
\text { rotations declining }\end{array}$ & $\begin{array}{l}\text { Current: poor rotations } \\
\text { Future: poor rotations } \\
\text { remain frequent }\end{array}$ & $\begin{array}{l}\text { Current: very diverse } \\
\text { rotation } \\
\text { Future: diversity of } \\
\text { rotations decining }\end{array}$ \\
\hline $\begin{array}{l}\text { Current labour } \\
\text { availability } \\
\text { and } \\
\text { future labour } \\
\text { availability }\end{array}$ & $\begin{array}{l}\text { Current: labour scarce } \\
\text { Future: persistent labour } \\
\text { scarcity }\end{array}$ & $\begin{array}{l}\text { Current: labour } \\
\text { extremely scarce } \\
\text { Future: persistent labour } \\
\text { scarcity }\end{array}$ & $\begin{array}{l}\text { Current: agricultural } \\
\text { labour available } \\
\text { Future: agricultural } \\
\text { labour declining }\end{array}$ \\
\hline $\begin{array}{l}\text { Current pesticide } \\
\text { use and } \\
\text { future pesticide } \\
\text { use }\end{array}$ & $\begin{array}{l}\text { Current: high to very high } \\
\text { Future: declining } \\
\text { (improvernent) }\end{array}$ & $\begin{array}{l}\text { Current: nil to low } \\
\text { Future harp increase } \\
\text { (dependence } \\
\text { pesticides) }\end{array}$ & $\begin{array}{l}\text { Current: low to } \\
\text { moderate } \\
\text { Future: sharp increase } \\
\text { (dependence on } \\
\text { pesticides) }\end{array}$ \\
\hline $\begin{array}{l}\text { Current use of } \\
\text { host plant } \\
\text { resistances } \\
\text { (HPR) and } \\
\text { future HPR } \\
\text { deployment }\end{array}$ & $\begin{array}{l}\text { Current: moderate HPR } \\
\text { use and deployment } \\
\text { Future: improvement of } \\
\text { HPR deployment }\end{array}$ & $\begin{array}{l}\text { Current: low to moderate } \\
\text { HPR deployment } \\
\text { Future: increased and } \\
\text { improved HPR } \\
\text { deployment }\end{array}$ & $\begin{array}{l}\text { Current: moderate } \\
\text { deployment of } \\
\text { HPR, slow variety } \\
\text { turn-over } \\
\text { Future: faster HPR } \\
\text { turn-over }\end{array}$ \\
\hline
\end{tabular}

Fig. 3. Three agricultural settings and their possible evolution with global, including climate, change within a 2050 time horizon. Cell colors indicate current (first point in each cell) favorability for wheat cultivation (described in text) of the considered factor (green, favorable; yellow, mixed; and orange, unfavorable). Background arrows indicate trends on favorability, i.e., anticipated effects (second point of each cell) of the considered factor (improvement, stagnation, and decline) upon favorability of wheat cultivation. 
in the three considered agrosystems. Across agrosystems, and as production situations evolve within agrosystems, variation in disease risks is expected to occur in response to the following.

- Ecological requirements of plant pathogens. Differences in specific environmental requirements of plant pathogens lead to changes in the frequency and intensity of plant disease epidemics.

- Crop vulnerability. In differing production situations (or as production situations evolve), the physiological status of crops changes, and so will the crop loss response to a given level of disease injury.

The levels of risk probability and risk magnitude discussed below result from expert consultations among the authors of this analysis. Conversely, the variations of disease risk probability and magnitude that accompany the evolution of agrosystems are hypothetical, based on the expected effects of the drivers of change on diseases. Underpinning these hypotheses are the effects of (i) climate, (ii) fertilizer inputs, (iii) tillage, and (iv) crop rotation. The latter three factors are associated with (v) labor availability (Zadoks 2013). Also to be considered in the case of plant diseases are additional elements of the technology level (Rabbinge and Van Oijen 1997) pertaining to agrosystems under change, such as the extent of pesticide usage, and the level of deployment (coverage and turnover) of host plant resistances. Another hypothesized effect is that of pesticides, which we assume, at a given level of technology, to be more efficient, because better targeted, in small farms in the order of $10^{0-1}$ ha compared with large farms of $10^{2-3}$ ha. This is because, in small-scale farming, disease problems are likely to be detected earlier, and control options implemented faster than in very large farms (assuming technology levels being the same). On the other hand, the efficiency of disease control from yet-to-come breeding results are assumed to have strong effects, irrespective of the considered farm acreage.

Risk probabilities and magnitudes are considered in a categorized fashion (Sundström et al. 2014), with three levels. Risk probabilities are classified from "high" when epidemics occur every 1 to 2 years, to "moderate" when epidemics occur every 3 to 5 years, and "low" when epidemics occur every 6 to 10 years. Similarly, three levels for

TABLE 1. A typology of infectious diseases in wheat based on epidemiological characteristics and damage mechanisms ${ }^{\mathrm{a}}$

\begin{tabular}{|c|c|c|c|c|c|c|c|}
\hline $\begin{array}{l}\text { Disease } \\
\text { type }\end{array}$ & $\begin{array}{l}\text { Diseases } \\
\text { caused by }\end{array}$ & Pathogens & $\begin{array}{l}\text { General biology } \\
\text { of pathogens }\end{array}$ & Dispersal & Survival & $\begin{array}{c}\text { Damage } \\
\text { mechanisms }\end{array}$ & $\begin{array}{l}\text { Current (future) } \\
\text { control }\end{array}$ \\
\hline FHB & Fusarium spp. & $\begin{array}{l}\text { Fusarium } \\
\text { graminearum, } \\
\text { F. avenaceum } \\
\text { F. culmorum, F. poae, } \\
\text { F. langsethiae, } \\
\text { F. sporotrichioides, } \\
\text { F. verticillioides, } \\
\text { etc. }\end{array}$ & $\begin{array}{l}\text { Very large inoculum } \\
\text { production, strong } \\
\text { survival capacity } \\
\text { (saprotrophs). } \\
\text { Infect grasses, small } \\
\text { grains, and nongrass } \\
\text { host crops. }\end{array}$ & $\begin{array}{l}\text { Wind, water } \\
\text { splash, } \\
\text { infected seed }\end{array}$ & $\begin{array}{l}\text { Crop residues, } \\
\text { mycelium, seed }\end{array}$ & $\begin{array}{l}\text { Water transport, } \\
\text { light stealer, } \\
\text { mycotoxin } \\
\text { production }\end{array}$ & $\begin{array}{l}\text { Fungicides, crop } \\
\text { rotation, (host } \\
\text { plant resistance) }\end{array}$ \\
\hline Bio & $\begin{array}{l}\text { Biotrophic } \\
\text { fungi }\end{array}$ & $\begin{array}{l}\text { Puccinia triticina, } \\
\text { P. striiformis, } \\
\text { P. graminis } \\
\text { f. sp. tritici } \\
\text { Blumeria graminis } \\
\text { f. sp. tritici }\end{array}$ & $\begin{array}{l}\text { Many cycles over a } \\
\text { growing season, large } \\
\text { inoculum production. } \\
\text { Highly specialized } \\
\text { pathogens. }\end{array}$ & Wind & $\begin{array}{l}\text { Mycelium, } \\
\text { alternate host, } \\
\text { "green bridge" }\end{array}$ & $\begin{array}{l}\text { Assimilate } \\
\text { consumption, } \\
\text { transpiration }\end{array}$ & HPR, fungicides \\
\hline Sep & $\begin{array}{l}\text { Septorial } \\
\text { Stagonospora }\end{array}$ & $\begin{array}{l}\text { Zymoseptoria tritici, } \\
\text { Parastagonospora } \\
\text { nodorum }\end{array}$ & $\begin{array}{l}\text { Several cycles over a } \\
\text { growing season, fairly } \\
\text { large inoculum } \\
\text { production. } \\
\text { Fairly specialized } \\
\text { pathogens with } \\
\text { saprotrophic abilities. }\end{array}$ & $\begin{array}{l}\text { Rain splash, } \\
\text { wind (seed) }\end{array}$ & $\begin{array}{l}\text { Crop residues, } \\
\text { mycelium (seed) }\end{array}$ & $\begin{array}{l}\text { Light stealer, } \\
\text { senescence } \\
\text { accelerator }\end{array}$ & $\begin{array}{l}\text { Fungicides, } \\
\text { tillage, crop } \\
\text { rotation, host } \\
\text { plant resistance }\end{array}$ \\
\hline $\mathrm{Nec}$ & $\begin{array}{l}\text { Necrotrophic } \\
\text { fungi }\end{array}$ & $\begin{array}{l}\text { Pyrenophora } \\
\text { tritici-repentis, } \\
\text { Cochliobolus } \\
\text { sativus, Alternaria } \\
\text { triticina }\end{array}$ & $\begin{array}{l}\text { Several cycles over a } \\
\text { growing season. Large } \\
\text { inoculum production, } \\
\text { strong survival capacity } \\
\text { as saprotrophs. }\end{array}$ & $\begin{array}{l}\text { Wind, rain } \\
\text { splash (seed) }\end{array}$ & $\begin{array}{l}\text { Crop residues, } \\
\text { mycelium, seed }\end{array}$ & $\begin{array}{l}\text { Light stealer, } \\
\text { senescence } \\
\text { accelerator, } \\
\text { stand reducer }\end{array}$ & $\begin{array}{l}\text { Fungicides, } \\
\text { tillage, crop } \\
\text { rotation, (host } \\
\text { plant resistance) }\end{array}$ \\
\hline Soil-b & $\begin{array}{l}\text { Root and } \\
\text { stem base } \\
\text { pathogens }\end{array}$ & $\begin{array}{l}\text { 1. Gaeumannomyces } \\
\text { graminis } \\
\text { 2. Oculimacula } \\
\text { yallundae } \\
\text { 3. Rhizoctonia } \\
\text { cerealis } \\
\text { 4. Cochliobolus } \\
\text { sativus, Fusarium } \\
\text { spp. } \\
\text { 5. Viruses transmitted } \\
\text { by Polymyxa } \\
\text { graminis: SBCMV, } \\
\text { SBWMV }\end{array}$ & $\begin{array}{l}\text { Soil-inhabiting organisms } \\
\text { with extremely variable } \\
\text { survival ability in } \\
\text { absence of the host, } \\
\text { from very low } \\
\text { (G. graminis) to high } \\
\text { (R. cerealis). } \\
\text { Specialization ranging } \\
\text { from low ( } R \text {. graminis) } \\
\text { to high }(O . \text { yallundae, } \\
\text { viruses). }\end{array}$ & $\begin{array}{c}\text { Soil, plant } \\
\text { material }\end{array}$ & $\begin{array}{l}\text { Crop residues, } \\
\text { resting structures } \\
\text { (seed) }\end{array}$ & $\begin{array}{l}\text { Stand reducer, } \\
\mathrm{H} 2 \mathrm{O} \text { transport, } \\
\text { photosynthesis } \\
\text { rate (virus) }\end{array}$ & $\begin{array}{l}\text { Crop rotation, } \\
\text { tillage, } \\
\text { fungicides, (host } \\
\text { plant resistance) }\end{array}$ \\
\hline Vir & $\begin{array}{l}\text { Viruses } \\
\text { transmitted } \\
\text { by flying } \\
\text { insects }\end{array}$ & $\begin{array}{l}\text { Barley yellow dwarf } \\
\text { diseases (BYD) }\end{array}$ & $\begin{array}{l}\text { BYD encompasses a } \\
\text { diversity of virus } \\
\text { species related to their } \\
\text { main (circulative } \\
\text { nonpropagative) insect } \\
\text { vectors. Inoculum } \\
\text { sources are infected } \\
\text { grass and small grain } \\
\text { hosts. }\end{array}$ & Aphids & $\begin{array}{l}\text { Aphids, grass } \\
\text { hosts, "green } \\
\text { bridge", }\end{array}$ & $\begin{array}{l}\text { Photosynthesis } \\
\text { rate, stand } \\
\text { reducer }\end{array}$ & $\begin{array}{l}\text { Control of vectors, } \\
\text { landscape and } \\
\text { escape }\end{array}$ \\
\hline
\end{tabular}

a Pathogen functional groups: FHB, organisms causing Fusarium head blight; Bio, biotrophic fungi; Sep, organisms causing Septoria diseases; Nec, necrotrophic fungi; Soil-b, root and stem base pathogens; and Vir, viruses transmitted by flying insects. 
risk magnitude are considered, from high for epidemics causing crop losses higher than $10 \%$ of the attainable yield, to moderate for crop losses lower than $10 \%$ but higher than $5 \%$, and low for crop losses lower than $5 \%$.

\section{PATTERNS OF CHANGE IN WHEAT DISEASES}

Climate and wheat diseases. Among the factors that may affect the importance of diseases, climate is often considered first. The six pathogen functional groups of Table 1, and the diseases they cause, correspond to quite different behaviors with respect to shifting climate (Table 2). FHB for instance is strongly associated with warm and humid late-springs or early-summers, which enhance infection of wheat flowers (McMullen et al. 1997; Parry et al. 1995; Xu 2003). The biotrophic pathogens (Bio), on the other hand, exhibit a very wide range of climatic adaptations. Some of the diseases listed in the Bio group of Table 1 have classically been associated with cold springs (e.g., stripe rust, Chen et al. 2014), others with cool, humid, but not rainy conditions (e.g., powdery mildew, Cunfer 2002), and others again with warm summers (e.g., leaf and stem rust, Roelfs and Bushnell 1985). General patterns may however vary, as has been the case in recent years in the case of stripe rust (Chen et al. 2014). Diseases listed in Sep (Table 1) have classically been associated with relatively cool and rainy growing seasons, largely in relation with their splash dispersal mechanisms (Brennan et al. 1985). Extended leaf wetness durations also strongly favor these diseases (Eyal 1999; Hess and Shaner 1987). The Necrotroph group ( $\mathrm{Nec}$ ) corresponds to diseases which perhaps are among the most strongly associated with climate, however in an indirect way: climatic conditions are often linked with disease establishment and expansion through climate-induced physiological stresses of the host (Duveiller et al. 2005). Heat and drought stresses of the host crop, which may occur together with sufficient leaf wetness for infection to take place, have been associated with these diseases (Duveiller et al. 2005; Gurung et al.2012). The soilborne pathogens (Soil-b) cover such a range of organisms and resulting diseases that this group may adapt to climate conditions wider, perhaps, than wheat cultivation itself. Important climate effects in this group include those which may affect the primary inoculum, such as cold winter suppressing the Polymyxa vectors, or wet summers favorable for infections of Gaeumannomyces graminis, causing take-all. Many of the climate factors to consider in the last group (Vir) pertain to effects on the insect vectors. For instance, warmer winters have been associated with stronger carryover of vector populations, and increased BYDV epidemics in winter wheat (Harrington 2002).

Nitrogen fertilizer and wheat diseases. The importance of nitrogen for wheat production (Mueller et al. 2012), the connection of nitrogen fertilizers with global energy issues (Smil 2000), and the extensive documentation of $\mathrm{N}$-fertilizer effects on wheat diseases leads us to isolate this element as a factor on its own (Table 2). The reported effects of N-fertilizer on FHB (Parry et al. 1995) have been variable. However, there is a body of reports indicating that $\mathrm{N}$-fertilizer enhances the biotrophs (Bio), in two main ways. First, healthy and green wheat tissues provide a more conducive habitat for biotrophic pathogens in terms of infection, lesion development, and propagule formation. Second, profuse crop growth in general ensures favorable microclimatic conditions (light, moisture) for infection, while facilitating propagule interception by healthy plants, at least in the beginning of epidemics (Zadoks and Schein 1979). The effects of $\mathrm{N}$-fertilization on Sep are analogous, at least in terms of indirect effects on the microclimate that favors these diseases (extended wet periods enabling infection, interception of splash-dispersed spores (Simón et al. 2005). With nitrogen starvation generating a stress of its own, and reducing the efficiency of the root system (Eckersten and Jansson 1991), the opposite is generally reported in the case of the necrotrophs (Nec): nutrient deficiency, especially nitrogen deficiency, has been associated with necrotrophic pathogens, especially spot blotch (Duveiller and Dubin 2002; Duveiller et al. 2005). Generalization of an overall nitrogen effect on Soil-b is very difficult; for take-all alone, effects of the nature of the $\mathrm{N}$-fertilizer have been documented (Hornby 1998). The literature pertaining to Vir suggests an enhancement of insect-transmitted viruses of the BYDV group when nitrogen supply is adequate. Modeling work for instance suggests that persistence in the vector (such as occurs for the viruses of the BYDV group) increases the rate of virus spread for a vector preferring healthy hosts more than it increases the rate of virus spread for a vector preferring diseased hosts (McElhany et al. 1995). Experimental work also indicates that higher nitrogen fertilizer increases aphid population density by increasing insect longevity and fecundity and by decreasing the time to maturity (Aqueel and Leather 2011).

Tillage and wheat diseases. One of the most powerful examples to illustrate the effects of crop management on plant disease may have become FHB of wheat and small grains (Table 2). The engine of an FHB epidemic is the size of its primary inoculum (Savary 2014; Xu 2003), which can be dispersed over very large distances. There is a body of literature (Bateman et al. 2007; McMullen et al. 1997; Parry et al. 1995; Schaafsma et al. 2005) supporting the hypothesis that no-till, or conservation tillage practices in general, which amount to amplifying the size of the source of primary inoculum, are one of the primary causes of the devastating epidemics on wheat crops of the Red River Valley (United States) in the 1990s, and recurrently afterward in the great plains of the New World. The role of conservation tillage is such a success for soil, water, and energy conservation, that reverting back to conventional tillage cannot be considered in these environments (De Wolf et al. 2003; McMullen et al. 2012; Willyerd et al. 2012). Where conventional tillage is an established component of cropping practices, combinations of other, incompletely efficient disease management approaches are necessary, including crop rotations, targeted fungicide applications, and (if and when available) partial host plant resistance (De Wolf et al. 2003; McMullen et al. 2012; Willyerd et al. 2012). Little information exists on the effect of tillage on the Bio group, except that no-till may increase the density of volunteers, thus generating green bridges for inoculum. Recent research suggests that tillage at the landscape scale reduces the primary inoculum of one of the Sep pathogens (Suffert et al. 2011). Similarly, no-till appears to favor tan spot (Duveiller et al. 2007), a member of the Nec group. However, because it also enables a faster crop establishment, and thus, to escape the heat waves of the beginning of the monsoon, no-till actually appears to enable the avoidance of spot blotch in the rice-wheat rotation of South Asia (Duveiller et al. 2007). Since the early ages of agriculture (Zadoks 2013), tillage has been, and still is, key to the management of many soilborne diseases (Soil-b; Bailey and Lazarovits 2003) since tillage reduces inoculum survival for many plant pathogens and favors antagonistic microorganisms. Cephalosporium stripe (a member of the Soil-b group) thus also appears to be a crop management-induced disease (Bockus and Shroyer 1998). In the case of the vector-transmitted viruses (Vir), it appears, by contrast, that no-tillage reduces barley yellow dwarf, because it reduces aphid populations (Kennedy et al. 2010). Table 2 indicates that the overall effects of tillage on wheat diseases are complex, which may be summarized as follows.

- Tillage suppresses disease when it reduces the primary inoculum for the diseases that strongly depend on primary inoculum buildup for their dynamics; this is especially the case with FHB and Soil-b, and also occurs with Sep and some Nec.

- Tillage may favor disease when it prevents the escape of crops from disease (some Nec), or does not prevent, and even favors, the build-up of primary inoculum (Vir, at least in some cases).

Firmer conclusions would be desirable; what appears to be lacking still is a better understanding of inoculum build-up over many successive seasons, through polyetic processes (Zadoks and Schein 1979), and of the interactions between polyetic processes 
and processes at a landscape scale. The issue of interactions between inoculum polyetic build-up, source strength, and dispersal are particularly apparent for diseases where the primary inoculum plays a defining role (Savary 2014), as in the case of FHB (Willyerd et al. 2012). This is an area of important progress for collective disease management through collective, landscape-based, action (Bergamin Filho et al. 2016; Yuen and Mila 2015).

Crop rotation and wheat diseases. Plant pathologists forewarned the danger of wheat-maize rotation with respect to FHB (Zadoks and Schein 1979). Today, diversifying crop rotations away

TABLE 2. Effects of current drivers of change on the importance (probability of epidemic and magnitude of crop losses) of wheat diseases ${ }^{\mathrm{a}}$

\begin{tabular}{|c|c|c|c|c|c|c|}
\hline \multirow{2}{*}{$\begin{array}{l}\text { Environmental } \\
\text { factors }\end{array}$} & \multicolumn{6}{|c|}{ Pathogen functional groups } \\
\hline & FHB & Bio & Sep & $\mathrm{Nec}$ & Soil-b & Vir \\
\hline Climate & $\begin{array}{l}\text { Favored by warm and } \\
\text { humid conditions at } \\
\text { anthesis (Parry et al. } \\
\text { 1995; Xu 2003) }\end{array}$ & $\begin{array}{l}\text { Biotrophic pathogens } \\
\text { in wheat collectively } \\
\text { exhibit a considerable } \\
\text { flexibility to adapt to } \\
\text { a wide range of } \\
\text { climates (Bockus } \\
\text { et al. 2010; Roelfs and } \\
\text { Bushnell 1985) }\end{array}$ & $\begin{array}{l}\text { Infection (from } \\
\text { ascospores and } \\
\text { pycniospores) favored } \\
\text { by rain (Eyal 1999) }\end{array}$ & $\begin{array}{l}\text { Heat stress favors } \\
\text { spot blotch } \\
\text { (Duveiller et al. } \\
\text { 2007) } \\
\text { Leaf wetness favors } \\
\text { tan spot and spot } \\
\text { blotch (Gurung } \\
\text { et al. 2012) }\end{array}$ & $\begin{array}{l}\text { Cold autumns } \\
\text { suppress SBCMV } \\
\text { and SBWMV } \\
\text { (Cadle-Davidson } \\
\text { and Bergstrom } \\
\text { 2004) }\end{array}$ & $\begin{array}{l}\text { Insect-transmitted } \\
\text { viruses expected to } \\
\text { become more } \\
\text { important due to } \\
\text { global warming even } \\
\text { in cool climates } \\
\text { (BYDV; Ordon et al. } \\
\text { 2009) }\end{array}$ \\
\hline $\begin{array}{l}\text { Fertilizer }(\mathrm{N}) \\
\text { inputs }\end{array}$ & $\begin{array}{l}\text { Variable effects } \\
\text { reported (Parry et al. } \\
1995)\end{array}$ & $\begin{array}{l}\text { Nitrogen increases } \\
\text { diseases caused by } \\
\text { biotrophs (De Wit } \\
\text { 1992) }\end{array}$ & $\begin{array}{l}\text { Nitrogen enhances } \\
\text { disease intensity } \\
\text { (Leitch and Jenkins } \\
\text { 1995) }\end{array}$ & $\begin{array}{l}\text { Nutrient deficiency } \\
\text { favors disease } \\
\text { (Gurung et al. 2012) }\end{array}$ & $\begin{array}{l}\text { The effects of } \\
\text { fertilizers on soil- } \\
\text { borne pathogens are } \\
\text { diverse and complex } \\
\text { (Bailey and } \\
\text { Lazarovits 2003) }\end{array}$ & $\begin{array}{l}\text { Higher nitrogen } \\
\text { increases aphid } \\
\text { populations (Aqueel } \\
\text { and Leather 2011) }\end{array}$ \\
\hline \multirow[t]{2}{*}{ Tillage } & $\begin{array}{l}\text { No or minimum } \\
\text { tillage favors } \\
\text { inoculum survival and } \\
\text { mobilization (Bailey } \\
\text { et al. 2001; Parry et al. } \\
\text { 1995; Xu 2003) }\end{array}$ & & $\begin{array}{l}\text { Tillage at large scale } \\
\text { may reduce primary } \\
\text { inoculum (Suffert } \\
\text { et al. } 2011 \text { ) }\end{array}$ & $\begin{array}{l}\text { No-till favors tan } \\
\text { spot (Duveiller et al. } \\
2007) \text {, caused by } \\
\text { a residue-borne } \\
\text { pathogen (Bockus } \\
\text { and Shroyer 1998) }\end{array}$ & $\begin{array}{l}\text { Tillage and crop } \\
\text { rotation lower soil } \\
\text { inoculum, reduce its } \\
\text { survival, favor } \\
\text { antagonistic } \\
\text { micro-organisms } \\
\text { (Bailey and } \\
\text { Lazarovits 2003) }\end{array}$ & $\begin{array}{l}\text { Minimum tillage } \\
\text { reduces epidemic } \\
\text { risks (vector } \\
\text { population and } \\
\text { infection; BYDV; } \\
\text { Kennedy et al. 2010) }\end{array}$ \\
\hline & & & & $\begin{array}{l}\text { No-till permits } \\
\text { earlier sowing and } \\
\text { allows escape from } \\
\text { spot blotch in warm } \\
\text { climates (Duveiller } \\
\text { et al. 2007) }\end{array}$ & $\begin{array}{l}\text { No-till enhances } \\
\text { Cephalosporium } \\
\text { stripe (Bockus and } \\
\text { Shroyer 1998) }\end{array}$ & $\begin{array}{l}\text { Maize residues may } \\
\text { favor epidemics } \\
\text { (BYDV; Cowger et al. } \\
\text { 2010) }\end{array}$ \\
\hline Crop rotation & $\begin{array}{l}\text { Crop rotation with } \\
\text { wheat and maize } \\
\text { increases inoculum } \\
\text { density (Roelfs and } \\
\text { Bushnell 1985; } \\
\text { Xu 2003) }\end{array}$ & & $\begin{array}{l}\text { Diversified crop } \\
\text { rotation at large scale } \\
\text { may reduce primary } \\
\text { inoculum (Suffert } \\
\text { et al. 2011) }\end{array}$ & $\begin{array}{l}\text { Tan spot may be } \\
\text { controlled by crop } \\
\text { rotations and } \\
\text { resistance in } \\
\text { conventional tillage } \\
\text { (Duveiller et al. } \\
\text { 2007) }\end{array}$ & $\begin{array}{l}\text { Crop rotations with } \\
\text { nonhost crops } \\
\text { reduce inoculum } \\
\text { (Bockus et al. 2010) }\end{array}$ & $\begin{array}{l}\text { Avoidance of } \\
\text { overlapping of } \\
\text { (alternate) host crops } \\
\text { reduces disease risk } \\
\text { probability at } \\
\text { landscape scale } \\
\text { (BYDV; Bockus et al. } \\
\text { 2010) }\end{array}$ \\
\hline $\begin{array}{l}\text { Labor } \\
\text { availability }\end{array}$ & $\begin{array}{l}\text { Limited labor } \\
\text { translating in low-or } \\
\text { no tillage, and limited } \\
\text { flexibility for } \\
\text { fungicide timing, may } \\
\text { favor the disease }\end{array}$ & & & $\begin{array}{l}\text { Limited labor } \\
\text { translating in low- } \\
\text { or no tillage may } \\
\text { favor disease }\end{array}$ & & \\
\hline Pesticide use & $\begin{array}{l}\text { Partial effect of } \\
\text { fungicides, partly due } \\
\text { to difficulty of spray } \\
\text { timing (McMullen } \\
\text { et al. 2012) }\end{array}$ & & $\begin{array}{l}\text { High evolutionary } \\
\text { capacity (McDonald } \\
\text { and Linde 2002; } \\
\text { Duveiller et al. 2007) } \\
\text { Efficiency of } \\
\text { fungicides challenged } \\
\text { by population } \\
\text { adaptation } \\
\text { (O'Driscoll et al. } \\
2014 \text { ) }\end{array}$ & $\begin{array}{l}\text { Efficiency of } \\
\text { fungicides } \\
\text { challenged by } \\
\text { pathogen adaptation } \\
\text { (e.g., tan spot) }\end{array}$ & & $\begin{array}{l}\text { Pesticide use } \\
\text { efficiency (to control } \\
\text { BYDV vectors) is low } \\
\text { (Bockus et al. 2010) }\end{array}$ \\
\hline $\begin{array}{l}\text { Deployment } \\
\text { of host plant } \\
\text { resistances } \\
\text { (HPR) }\end{array}$ & $\begin{array}{l}\text { Varieties with } \\
\text { quantitative resistance } \\
\text { released (Bai and } \\
\text { Shaner 2004; } \\
\text { McMullen et al. 2012) }\end{array}$ & $\begin{array}{l}\text { High evolutionary } \\
\text { capacity (McDonald } \\
\text { and Linde 2002) } \\
\text { Resistances (mainly } \\
\text { complete) deployed } \\
\text { over decades } \\
\text { Combinations of } \\
\text { minor genes of } \\
\text { resistance are } \\
\text { effective (Duveiller } \\
\text { et al. 2007) }\end{array}$ & $\begin{array}{l}\text { Partial resistance } \\
\text { identified, but } \\
\text { currently poorly } \\
\text { deployed (O'Driscoll } \\
\text { et al. 2014) }\end{array}$ & $\begin{array}{l}\text { Partial resistance } \\
\text { identified, but slow } \\
\text { progress in } \\
\text { development of } \\
\text { HPR against spot } \\
\text { blotch (Duveiller } \\
\text { et al. 2007) }\end{array}$ & $\begin{array}{l}\text { Sources of HPR } \\
\text { have been reported } \\
\text { (cereal nematodes } \\
\text { and root rots; } \\
\text { Duveiller et al. } \\
2007 \text { ) }\end{array}$ & $\begin{array}{l}\text { Few resistant varieties } \\
\text { available (BYDV; } \\
\text { Bockus et al. 2010) }\end{array}$ \\
\hline
\end{tabular}

a Pathogen functional groups: FHB, organisms causing Fusarium head blight; Bio, biotrophic fungi; Sep, organisms causing Septoria diseases; Nec, necrotrophic fungi; Soil-b, root and stem base pathogens; and Vir, viruses transmitted by flying insects. 
from wheat-maize, or from wheat with other Fusarium-susceptible crops, is seen as an important way to manage FHB (Willyerd et al. 2012). Crop rotation may also contribute to manage Sep (Suffert et al. 2011), tan spot (Duveiller et al. 2007), and remains a principal management option for several Soil-b diseases (Bockus et al. 2010).

Agricultural labor and wheat diseases. Table 2 includes agricultural labor as one over-arching resource that contributes to the importance of wheat diseases in agrosystems. Agricultural labor actually underpins, and overlaps with, tillage and rotations, but also determines a number of crop husbandry practices leading to differing crop health status. Availability of labor for instance determines the degree of crop health monitoring that leads in some production situations to careful planning as well as to customizing the site- and time-specificity of management actions, while labor shortage contributes to blanket decisions in other production situations.

Pesticide use and wheat diseases. Pesticide use, its prevalence and efficiency, is to be considered in nearly all wheat pathogen functional groups (Table 2). Fungicides have become an important management component for FHB (Willyerd et al. 2012) despite difficulties of implementation (McMullen et al. 2012). Fungicides constitute the main management component to control Sep diseases in Agrosystem 1, and are used frequently in Agrostem 2. This is in spite of the genetic flexibility of Sep pathogens and their adaptation to chemicals (Duveiller et al. 2007; O'Driscoll et al. 2014). Adaptation to synthetic fungicides applies to any of the pathogen groups where rapid evolutionary capabilities may be expressed (McDonald and Linde 2002). This problem is becoming especially acute in Agrosystem 1, where for instance the efficiency of two types of fungicides, triazoles and QoIs (strobilurins), has declined over time in the UK when used against Sep, powdery mildew in the Bio group, and tan spot in the Nec group (Fraaije et al. 2005, 2007).

Host plant resistances and their deployment. Host plant resistances, their deployment, their temporal turnover, their efficiencies, are among the most important factors that both shape the landscapes of crop health in wheat-based agrosystems of the world, and constitute a critical instrument for disease management (Duveiller et al. 2007). This is especially true for the Bio pathogens, and to a lesser extent for the hemibiotrophic or the necrotrophic pathogens (Bockus et al. 2010; Duveiller et al. 2007; McDonald and Linde 2002). The use of combined minor genes for stripe and leaf rust in breeding programs over the last three decades is one of the best examples of development and deployment of efficient and durable resistance in varieties (Duveiller et al. 2007; Singh et al. 2016). These breeding efforts are associated with very large economic benefits, as shown in the case of leaf rust (Smale et al. 1998). The consideration of large scale ecological processes, including inoculum build-up, medium and long range dispersal, and pathogen re-establishment, in the spatial deployment of resistance genes has allowed an efficient control of stripe rust in China over recent decades (Chen et al. 2014). In the case of some groups of Table 1 (FHB and Vir), host plant resistances however only play an incomplete, partial role in disease management. The use of host plant resistance against FHB is foreseen as a management tool that needs to be combined with others in order to control FHB epidemics (McMullen et al. 2012).

\section{CURRENT AND FUTURE PATTERNS OF DISEASE RISKS}

Scenario analyses using the above processes and hypotheses were implemented for the six functional groups of wheat pathogens in the three agrosystems (Fig. 1) through consultation toward a consensus of a collective assessment on the present status of wheat health in the three agrosystems. Risk probabilities and magnitudes for (i) each of the six pathogen functional groups, (ii) in the three agrosystems, and (iii) in the present and foreseeable future, were assessed following three steps:

- First, Figure 3 provides a summary of the narratives for changes in the three agrosystems; these narratives include elements of the climate and of more specific components of production situations, including shifts in labor availability, and crop and pest management components.

- Second, the narratives of Figure 3 generate Table 2, which describes changes in environmental factors that will influence to varying degrees each of the six functional groups for wheat pathogens and associated diseases. The effects of these environmental factors (Fig. 3) may translate into consequences for diseases (Table 2) in terms of (i) primary inoculum, including amounts produced, genetic make-up and population structure, and survival over successive seasons, and (ii) infection and disease development processes.

- Third, disease risk probability and magnitude are inferred for each agrosystem (Fig. 4), present and future. Disease risk probability - the probability of an epidemic occurring-is linked to primary inoculum, while risk magnitude-the level of crop losses - is made a function of disease development in each considered agrosystem.

An overview of Figure 4 indicates varying patterns of functional groups (in terms of risk probability and magnitude) according to both time horizon and production situation. Agrosystem 1 is currently dominated by Bio (biotrophic pathogens) and Sep (Septoria diseases) in terms of both probabilities and magnitudes (in both cases, there are high probabilities of epidemics and moderate crop losses), while risk probabilities of FHB and Soil-b are high, but associated with low risk magnitudes. By contrast, the current status of Agrosystem 2 generally corresponds to lower risk probabilities compared with Agrosystem 1; however, the risk magnitudes of FHB and Nec (necrotrophic pathogens) are higher in Agrosystem 2 than in Agrosystem 1, to represent higher crop losses to these group in Agrosystem 2. Risk magnitudes for Bio and Sep are lower in Agrosystem 2. Agrosystem 3 contrasts with the two other agrosystems in its generally low levels of disease risk probabilities, except for Nec, which is considered high; risk magnitudes in Agrosystem 3 are also low, except for the biotrophs (Bio), which may cause very large crop losses when occurring, and the frequent (high risk probability) and often heavy losses (moderate risk magnitude) caused by necrotrophic pathogens.

The right side of Figure 4 offers a view of the foreseeable status of wheat health in the future. In Agrosystem 1, risk probabilities remain unchanged, while risk magnitudes (crop losses) in Bio and Sep diseases are decreased, but the risk magnitude in FHB is increased. In Agrosystem 2, all risk probabilities are increased, except for diseases caused by Bio pathogens. The associated magnitudes however remain mostly unchanged, except for an increase in the crop losses associated with biotrophic pathogens. In Agrosystem 3, the risk probabilities associated with FHB and biotrophic pathogens are increased; however, risk magnitudes associated with Sep and Nec are increased, while the risk magnitude associated with Bio decreases. As a result, the right side of Figure 4 suggests that there would be little changes in crop health in Agrosystem 1 in the future, except for a decline of crop losses caused by the two classic causes for concern in that system, Bio and Sep; but risk magnitude associated with FHB would increase. There is, in contrast, an inflation of risks (probability and magnitude) in Agrosystem 2: increases of risk probabilities of FHB, Sep, Nec, Soil-b, and Vir, and of risk magnitude in Bio. There are multiple risk increases also in Agrosystem 3, in terms of probability for FHB, and of magnitude for Sep and Nec, while the risk magnitude for Bio decreases. This series of hypotheses on future wheat health are synthesized in Table 2, and are further discussed below.

The overall pattern suggested by Figure 4 is that, while shifts in risk patterns might be small in Agrosystem 1, they might be much stronger-with higher probabilities and increased magnitudes-in Agrosystems 2 and 3 . As a result, projected global changes would lead to a higher level of uniformity of crop health risks across agrosystems. 


\section{DISCUSSION AND CONCLUSIONS}

The value of considering scenarios. This analysis is based on scenarios, which may be seen as idealized realization of many possible combinations of climates, natural resources, crop management, technological, economic and social environment (which we all combined under the phrase "production situation"), and plant diseases. Implicitly, each scenario contains its own logic: some cropping practices will be encountered under some climates, and not in others, for instance. As a result, a critical benefit of looking at

\section{Agrosystem 1: Small intensive farm, temperate agriculture}
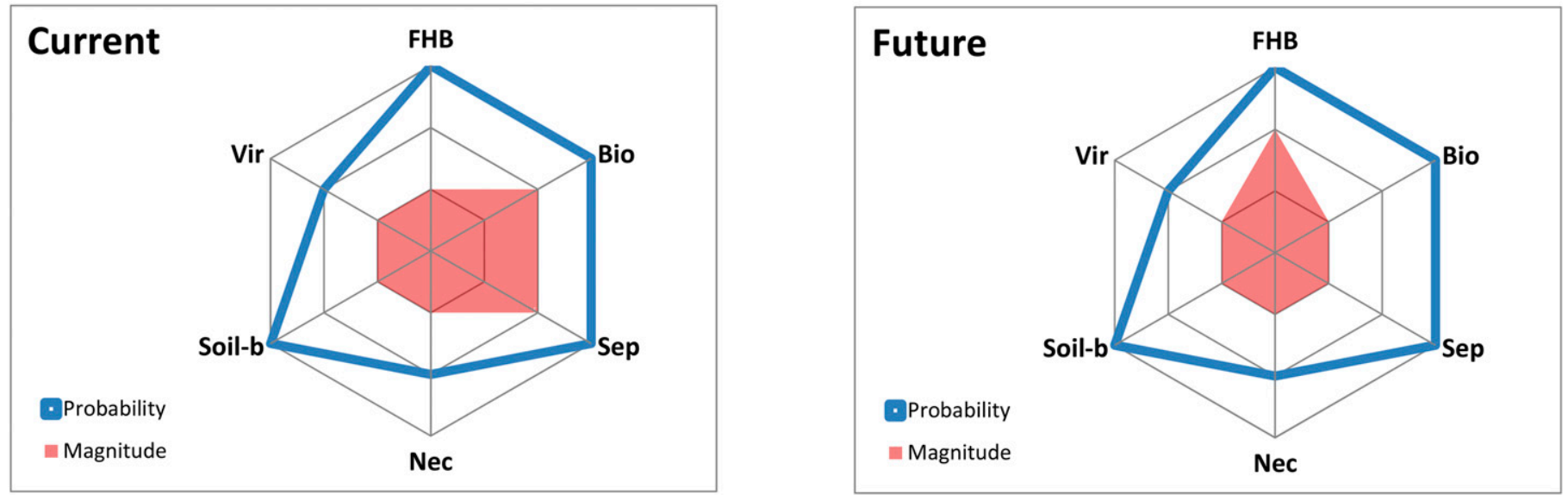

\section{Agrosystem 2: Extensive large farm}
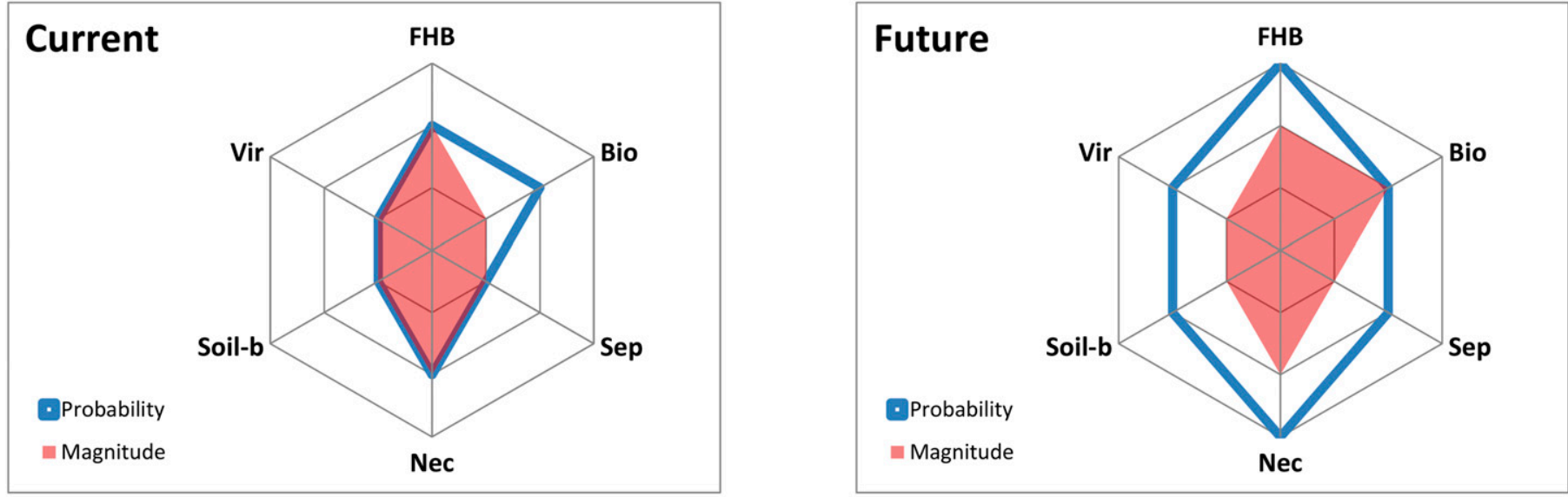

\section{Agrosystem 3: Semi-arid or transition climate farm}
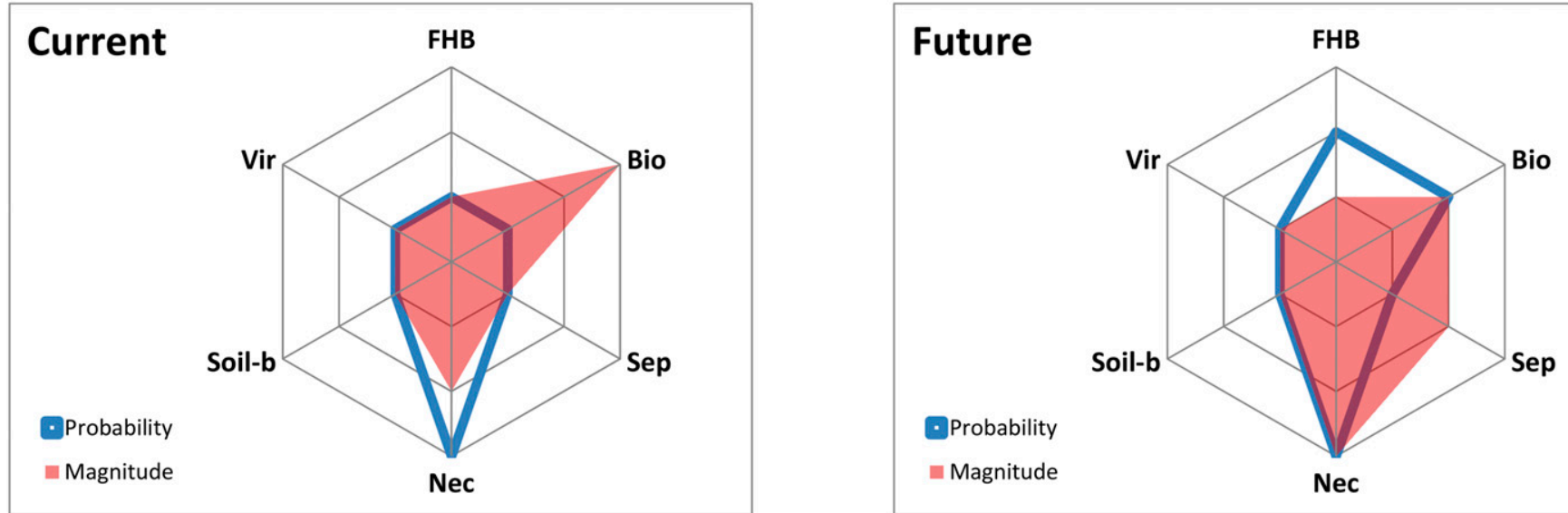

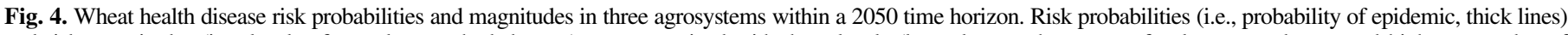

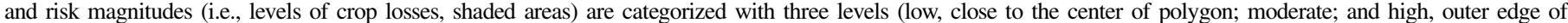

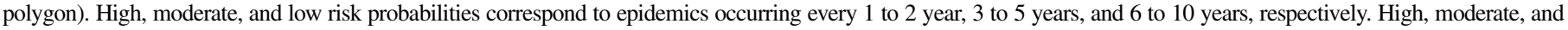

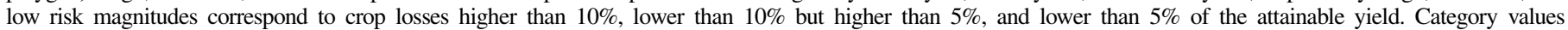

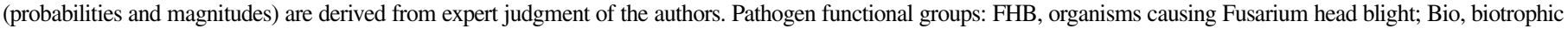
fungi; Sep, organisms causing Septoria diseases; Nec, necrotrophic fungi; Soil-b, root and stem base pathogens; and Vir, viruses transmitted by flying insects. 
diversity in the form of a few chosen scenarios, is that only a few of the very large number of possible combinations of factors, and of their interactions, are to be considered. In our examplification of scenario analysis in the case of wheat diseases, we emphasized the main effects of some factors. Interactions were not directly addressed.

Increases in disease risk probabilities and magnitudes. A main conclusion of this assessment is that an overall inflation of risks, both in probabilities and magnitudes, is envisioned in two of the three agrosystems we consider, in response to anticipated drivers of change. In particular, these increased risks concern the Septoria diseases (Sep), the diseases caused by biotrophic fungi (Bio), and the diseases caused by necrotrophic fungi $(\mathrm{Nec})$ in Agrosystems 2 and 3. These changes are, in our reasoning, largely associated with crop management: with the (even moderate) increase in nitrogen fertilizer inputs (Bio, Sep), and with expanding or more frequent use of reduced tillage ( $\mathrm{Sep}, \mathrm{Nec}$ ). Our assessment also leads us to see increased risks probabilities for the soilborne and insect-transmitted viruses in Agrosystem 2, again as a consequence of accounting for elements of system management, in this case, increased cropping intensity.

Climate change effects, especially effects mediated by the crop physiology, are also incorporated in our assessment. For instance, insufficient, or poorly distributed rainfall, leading to drought stress is accounted for in our assessment of the increased probability and magnitude of Nec in Agrosystem 2 and 3, respectively. This assessment conforms to several reports emphasizing the rising importance of necrotrophic pathogens with climate change and variability (Chakraborty et al. 2000; Duveiller et al. 2007).

Particular case of FHB. FHB is prominent in this analysis as the disease type which importance is assessed to clearly increase in all three agrosystems. Our assessment leads to an increase of FHB risk magnitude in Agrosystem 1, and of FHB risk probabilities in Agrosystems 2 and 3 (Fig. 4). These increased risks result from the superimposed, largely confounded and associated, impacts of climate change and variability with shifts in cropping practices in production situations: both the direct effects of climate change, and its indirect effects, combined with other drivers of global change (such as the decline of agricultural labor availability, or the increased costs of energy) are indicated to favor FHB epidemics and crop losses to FHB.

Decreases in disease risk probabilities and magnitudes. Not all wheat diseases are anticipated to increase in importance in our assessment. For instance, in the case of the diseases caused by biotrophic pathogens (Bio), a decrease in risk magnitude (crop losses) is anticipated in Agrosystem 1 (Fig. 4) as a result of decreasing fertilizer inputs, and possibly climatic conditions becoming less favorable for the intensification of these diseases. A decrease in risk magnitude of Bio is also anticipated in Agrosystem 3, with climatic environments becoming increasingly more uncertain-heat waves and drought spells.

Our assessments depend on the available epidemiological knowledge, but the framework is flexible enough to incorporate new information. For instance, our assessment for Sep in Agrosystem 1 is that of a decreased risk magnitude. This is primarily based on a projected climate with fewer rainfall events, and moderately reduced $\mathrm{N}$ fertilizer inputs. This assessment however discounts recent epidemiological findings (for Zymoseptoria tritici; Suffert and Sache 2011) showing the strong role that crop residues may play in initiating and sustaining initial epidemics. If reduced tillage were to spread in Agrosystem 1, this might balance the suppressive effects of climate change allowing the Sep risk magnitude at least to remain stable and fairly high.

Scenario analysis and simulation modeling. Simulation modeling has been advocated as a key approach to address issues where complex systems are influenced by multiple factors, as in crop health and climate change (Chakraborty et al. 2000). A simulation model may be seen as a theory meant to encapsulate phenomena through its structure (the processes it incorporates, and those it does not) and its parameters. Simulation modeling offers the possibility to integrate quantitative knowledge in a formal numerical synthesis, and produce quantitative outputs which are outcomes of the theory, which the simulation model represents (Rabbinge and De Wit 1989). Simulated outcomes, in turn, provide a quantitative basis to assess the value of the theory; they may offer ways to improve the theory with respect to observed phenomena (e.g., disease progress curves, crop losses); and they may point at further research needs. These properties have made simulation models important and useful research instruments. The synthesis of available wheat disease models developed by Juroszek and von Tiedemann (2013) highlights the potential of simulation modeling. These authors express the view that, by contrast to expert judgement (as is used in the qualitative scenario analysis of the present report), simulation outputs are less subjective (Juroszek and von Tiedemann 2013).

Another perspective is that, as the present work suggests, the indirect effects of climate change on the management of crop and agrosystem, i.e., shifts in production situations, might well be as important as, or even more important than, the direct effects of climate change on epidemiological and crop loss processes. While the implementation of climate change and climate variability in epidemiological and crop loss models might (seemingly) appear straightforward, the incorporation of shifts in production situations in simulation models probably is much more difficult. The difficulty lies, in particular, in the dilemma of developing either very detailed models, or simpler, generic ones. Detailed models may enable accounting for changes in production situations, which can be translated into a number of specific, yet important, changes (i) in epidemiological parameters (an important one would be the amount and time kernel of the primary inoculum), (ii) in host-pathogen characteristics (effects of microenvironmental factors on the disease cycle), (iii) in crop physiology and growth (water and nutritional effects), or (iv) in the physiology of the diseased crop. Generic, simple models, on the other hand, are much less demanding in parameters; they enable multiple diseases (and pests) to be addressed; they are transparent; and they are comparatively much easier to assess, share, and use.

Scenario analysis and simulation modeling are complementary, the former providing a framework (parameter spaces) for the latter (Rosenzweig and Hillel 2015). Furthermore, disease risk probabilities and disease risk magnitudes, which have been addressed qualitatively here, can respectively be quantified with epidemiological models (Savary et al. 2012, 2015) and crop loss models (Willocquet et al. 2000, 2002, 2004, 2008). Analyses of the effect of climate change, using epidemiological and crop loss models in sequence, were recently performed to assess the epidemiological and crop loss risks associated with bacterial leaf blight and leaf blast in rice in Tanzania (Duku et al. 2016). A similar approach could be used to address crop health risks under global change scenarios in different parts of the world, for different crops, and for the array of diseases affecting these crops.

Conclusions and perspectives. This work attempts to highlight the value of developing and applying scenario analyses to address crop health and its evolution with global changes. To our knowledge, this is the first time that a scenario analysis, involving multiple agricultural settings, multiple diseases, and a set of factors affecting them, has been applied in plant disease epidemiology. The results obtained in terms of framework development and in terms of scenario outcomes point to several benefits from such an approach in plant disease epidemiology. First its heuristic value: the approach is a powerful tool to organize hypotheses on key elements and interactions involved in a complex system. This further allows identifying knowledge gaps and research questions. Second, the approach allows identifying avenues for future research. In this report, scenario analysis was restricted to the evolution of three agrosystems according to a global scenario of change. Nevertheless, the analysis points at several crop health risks in wheat, which were outlined in the previous section. Research should engage or be strengthened on these priorities. 
Further work along the lines described in this report could include additional agrosystems, several scenarios of global change, and a deeper analysis of future disease management technologies. We considered three agrosystems that capture some key features of major wheat production areas in the world. Additional agricultural settings, for example niche-market-oriented agrosystems such as organic farming could be considered in future analyses. In this report, we addressed climate change in a very simplified way, using only one source (IPCC 2014). Several climate change patterns (scenarios) have been generated in several sources (Ciscar et al. 2014), which should be considered in a more detailed analysis. Therefore, a range of climatic and global scenarios could be considered in order to reveal more possible future outcomes. Current technologies for disease management mainly involve pesticides and host plant resistance. The future of these technologies could be analyzed according to their efficiency and durability, as well as to the capacity to produce new molecules or the integration of new genes in varieties. New technologies involving, e.g., remote sensing or high throughput data collection and analysis enabling a smarter agriculture could also be considered.

Ultimately, progress in crop health assessment will depend on the availability of data. Data on actual disease progress curves are necessary; but these only make sense in a context: accurate information on production situations (including crop varieties and cropping practices), together with weather data, is necessary, as well as quantitative information on crop growth, crop development, and yield. Chakraborty et al. (2000) pointed at the need for such data; this was repeated by Savary et al. (1996) and Willocquet et al. (2000, 2002) about rice health, and wheat (Willocquet et al. 2008). As a result, situations where such rich data sets on crop health, production situations, and crop performance are rare. This warrants approaches combining simulation modeling and scenario analysis.

The conceptual and methodological framework presented here enables a qualitative assessment of wheat health that may be helpful for research priority setting and for identifying crop health risks associated with changes in production situation. This type of approach is also compatible with quantitative approaches, such as simulation modeling. Scenario analysis may, from this perspective, be seen as a very general and unifying framework to explore the behavior of complex systems.

\section{ACKNOWLEDGMENTS}

This research was partly funded by the Sustainable Management of Crop Health $(\mathrm{SMaCH})$ meta-programme of INRA, which supported international travels and the Risk Analysis for Wheat health (RAW) Workshop held in Paris (March 10-12, 2014). E. M. Del Ponte acknowledges CNPq for a Special Visiting Researcher fellowship provided by the Science Without Border program to support visits of S. Savary to Brazil.

\section{LITERATURE CITED}

Aqueel, M. A., and Leather, S. R. 2011. Effect of nitrogen fertilizer on the growth and survival of Rhopalosiphum padi (L.) and Sitobion avenae (F.) (Homoptera: Aphididae) on different wheat cultivars. Crop Prot. 30:216-221.

Avelino, J., Willocquet, L., and Savary, S. 2004. Effects of crop management patterns on coffee rust epidemics. Plant Pathol. 53:541-547.

Ayres, P. G. (ed.) 1981. Effects of Disease on the Physiology of the Growing Plant. Cambridge University Press, Cambridge, U.K

Bai, G. H., and Shaner, G. 2004. Management and resistance in wheat and barley to Fusarium head blight. Annu. Rev. Phytopathol. 42:135-161.

Bailey, K. L., Gossen, B. D., Lafond, G. P., Watson, P. R., and Derksen, D. A. 2001. Effect of tillage and crop rotation on root and foliar diseases of wheat and pea in Saskatchewan from 1991 to 1998: Univariate and multivariate analyses. Can. J. Plant Sci. 81:789-803.

Bailey, K. L., and Lazarovits, G. 2003. Suppressing soil-borne diseases with residue management and organic amendments. Soil Tillage Res. 72:169-180.

Bateman, G. L., Gutteridge, R. J., Gherbawy, Y., Thomsett, M. A., and Nicholson, P. 2007. Infection of stem bases and grains of winter wheat by Fusarium culmorum and $F$. graminearum and effects of tillage method and maize-stalk residues. Plant Pathol. 56:604-615.
Bergamin Filho, A., Inoue-Nagata, A. K., Bassanezi, R. B., Belasque, J., Jr., Amorim, L., Macedo, M. A., Barbosa, J. C., Willocquet, L., and Savary, S. 2016. The importance of primary inoculum and area-wide disease management to crop health and food security. Food Secur. 8:221-238.

Bockus, W. W., Bowden, R. L., Hunger, R. M., Morrill, W. L., Murray, T. D., and Smiley, R. W. 2010. Compendium of Wheat Diseases and Pests, 3rd ed. American Phytopathological Society, St. Paul, MN.

Bockus, W. W., and Shroyer, J. P. 1998. The impact of reduced tillage on soilborne plant pathogens. Annu. Rev. Phytopathol. 36:485-500.

Boote, K. J., Jones, J. W., Mishoe, J. W., and Berger, R. D. 1983. Coupling pests to crop growth simulators to predict yield reductions. Phytopathology 73:1581-1587.

Bottalico, A., and Perrone, G. 2002. Toxigenic Fusarium species and mycotoxins associated with head blight in small-grain cereals in Europe. Eur. J. Plant Pathol. 108:611-624.

Breman, H., and De Wit, C. T. 1983. Rangeland productivity and exploitation in the Sahel. Science 221:1341-1347.

Brennan, R. M., Fitt, B. D., Taylor, G. S., and Colhoun, J. 1985. Dispersal of Septoria nodorum pycnidiospores by simulated rain and wind. J. Phytopathol. 112:291-297.

Brisson, N., Gate, P., Gouache, D., Charmet, G., Oury, F. X., and Huard, F. 2010. Why are wheat yields stagnating in Europe? A comprehensive data analysis for France. Field Crops Res. 119:201-212.

Brown, J. K., and Hovmøller, M. S. 2002. Aerial dispersal of pathogens on the global and continental scales and its impact on plant disease. Science 297: 537-541.

Cadle-Davidson, L., and Bergstrom, G. C. 2004. The effects of postplanting environment on the incidence of soilborne viral diseases in winter cereals. Phytopathology 94:527-534.

Cassman, K. G., and Wood, S. (eds.) 2005. Cultivated systems. Pages 745-794 in: Millennium Ecosystem Assessment. Ecosystems and Human WellBeing: Current State and Trends. Island Press, Washington, DC.

Chakraborty, S., and Newton, A. C. 2011. Climate change, plant diseases and food security: an overview. Plant Pathol. 60:2-14.

Chakraborty, S., Tiedemann, A. V., and Teng, P. S. 2000. Climate change: Potential impact on plant diseases. Environ. Pollut. 108:317-326.

Chen, W., Wellings, C., Chen, X., Kang, Z., and Liu, T. 2014. Wheat stripe (yellow) rust caused by Puccinia striiformis f. sp. tritici. Mol. Plant Pathol. 15:433-446.

Ciscar, J. C., Feyen, L., Soria, A., Lavalle, C., Raes, F., Perry, M., Nemry, F., Demirel, H., Rozsai, M., Dosio, A., Donatelli, M., Srivastava, A., Fumagalli, D., Niemeyer, S., Shrestha, S., Ciaian, P., Himics, M., Van Doorslaer, B., Barrios, S., Ibáñez, N., Forzieri, G., Rojas, R., Bianchi, A., Dowling, P., Camia, A., Libertà, G., San Miguel, J., de Rigo, D., Caudullo, G., Barredo, J. I., Paci, D., Pycroft, J., Saveyn, B., Van Regemorter, D., Revesz, T., Vandyck, T., Vrontisi, Z., Baranzelli, C., Vandecasteele, I., Batista e Silva, F., and Ibarreta, D. 2014. Climate Impacts in Europe. The JRC PESETA II Project. JRC Scientific and Policy Reports, EUR 26586EN.

Cowger, C., Weisz, R., Anderson, J. M., and Horton, J. R. 2010. Maize debris increases Barley yellow dwarf virus severity in North Carolina winter wheat. Agron. J. 102:688-695.

Cunfer, B. M. 2002. Powdery mildew. Pages 317-330 in: Bread Wheat: Improvement and Production, Plant Production and Protection Series No. 30. B. C. Curtis, S. Rajaram, and G. H. Macpherson, eds. FAO, Rome.

Dalsgaard, J. P. T., and Oficial, R. T. 1997. A quantitative approach for assessing the productive performance and ecological contributions of smallholder farms. Agric. Syst. 55:503-533.

De Wit, C. T. 1992. Resource use efficiency in agriculture. Agric. Syst. 40: 125-151.

De Wolf, E. D., Madden, L. V., and Lipps, P. E. 2003. Risk assessment models for wheat Fusarium head blight epidemics based on within season weather data. Phytopathology 93:428-435.

Del Ponte, E. M., Spolti, P., Ward, T. J., Gomes, L. B., Nicolli, C. P., Kuhnem, P. R., Silva, C. N., and Tessmann, D. J. 2015. Regional and field-specific factors affect the composition of Fusarium head blight pathogens in subtropical no-till wheat agroecosystem of Brazil. Phytopathology 105:246-254.

Duku, C., Sparks, A. H., and Zwart, S. J. 2016. Spatial modelling of rice yield losses in Tanzania due to bacterial leaf blight and leaf blast in a changing climate. Clim. Change 135:569-583.

Duveiller, E., and Dubin, H. J. 2002. Helminthosporium leaf blights: Spot blotch and tan spot. In: Bread Wheat. Improvement and Production. B.C. Curtis, S. Rajaram, and H. G. Macpherson, eds. FAO Plant Production and Protection Series No 30.

Duveiller, E., Kandel, Y. R., Sharma, R. C., and Shrestha, S. M. 2005. Epidemiology of foliar blights (spot blotch and tan spot) of wheat in the plains bordering the Himalayas. Phytopathology 95:248-256.

Duveiller, E., Singh, R. P., and Nicol, J. M. 2007. The challenges of maintaining wheat productivity: Pests, diseases, and potential epidemics. Euphytica 157:417-430. 
Easterling, D. R., Horton, B., Jones, P. D., Peterson, T. C., Karl, T. R., Parker, D. E., Salinger, M. J., Razuvayev, V., Plummer, N., Jamason, P., and Folland, C. K. 1997. Maximum and minimum temperature trends for the globe. Science 277:364-367.

Eckersten, H., and Jansson, P. E. 1991. Modelling water flow, nitrogen uptake and production for wheat. Fert. Res. 27:313-329.

Eriksen, L., and Munk, L. 2003. The occurrence of Mycosphaerella graminicola and its anamorph Septoria tritici in winter wheat during the growing season. Eur. J. Plant Pathol. 109:253-259.

Eyal, Z. 1999. The Septoria tritici and Stagonospora nodorum blotch diseases of wheat. Eur. J. Plant Pathol. 105:629-641.

FAO. 2016. Food and Agriculture Organization of the United Nations.

Fraaije, B. A., Cools, H. J., Fountaine, J., Lovell, D. J., Motteram, J., West, J. S., and Lucas, J. A. 2005. Role of ascospores in further spread of QoIresistant cytochrome b alleles (G143A) in field populations of Mycosphaerella graminicola. Phytopathology 95:933-941.

Fraaije, B. A., Cools, H. J., Kim, S. H., Motteram, J., Clark, W. S., and Lucas, J. A. 2007. A novel substitution I381V in the sterol $14 \alpha$-demethylase (CYP51) of Mycosphaerella graminicola is differentially selected by azole fungicides. Mol. Plant Pathol. 8:245-254.

Garrett, K. A., Forbes, G. A., Savary, S., Skelsey, P., Sparks, A. H., Valdivia, C., Van Bruggen, A. H. C., Willocquet, L., Djurle, A., Duveiller, E., Eckersten, H., Pande, S., Vera Cruz, C., and Yuen, Y. 2011. Complexity in climate-change impacts: An analytical framework for effects mediated by plant disease. Plant Pathol. 60:15-30.

Gosme, M., Willocquet, L., and Lucas, P. 2007. Size, shape and intensity of aggregation of take-all disease during natural epidemics in second wheat crops. Plant Pathol. 56:87-96.

Gurung, S., Sharma, R. C., Duveiller, E., and Shrestha, S. M. 2012. Comparative analyses of spot blotch and tan spot epidemics on wheat under optimum and late sowing period in South Asia. Eur. J. Plant Pathol. 134:257-266.

Harrington, R. 2002. BYDV: The heat is on. Pages 35-9 in: Barley Yellow Dwarf Disease: Recent Advances and Future Strategies. M. Henry and A. MacNab, eds. Proceedings of an International Symposium Held at El Batán, Texcoco, Mexico.

Hess, D. E., and Shaner, G. 1987. Effect of moisture on Septoria tritici blotch development on wheat in the field. Phytopathology 77:220-226.

Hobbs, P. R. 2007. Conservation agriculture: what is it and why is it important for future sustainable food production? J. Agric. Sci. 145:127-137.

Hobbs, P. R., Sayre, K., and Gupta, R. 2008. The role of conservation agriculture in sustainable agriculture. Philos. Trans. Roy. Soc. B Biol. Sci. 363:543-555

Hornby, D. 1998. Take-all Disease of Cereals: A Regional Perspective. CAB International, Wallingford, U.K.

IPCC. 2014. Climate Change 2014: Impacts, Adaptation, and Vulnerability. Part A: Global and Sectoral Aspects. Contribution of Working Group II to the Fifth Assessment Report of the Intergovernmental Panel on Climate Change. C. B. Field, V. R. Barros, D. J. Dokken, K. J. Mach, M. D. Mastrandrea, T. E. Bilir, M. Chatterjee, K. L. Ebi, Y. O. Estrada, R. C. Genova, B. Girma, E. S. Kissel, A. N. Levy, S. MacCracken, P. R. Mastrandrea, and L. L. White, eds. Cambridge University Press, Cambridge, U.K. and New York.

Juroszek, P., and von Tiedemann, A. 2013. Climate change and potential future risks through wheat diseases: A review. Eur. J. Plant Pathol. 136:21-33.

Keller, M. D., Bergstrom, G. C., and Shields, E. J. 2014. The aerobiology of Fusarium graminearum. Aerobiologia 30:123-136.

Kennedy, T. F., McDonald, J. G., Connery, J., and Purvis, G. 2010. A comparison of the occurrence of aphids and Barley yellow dwarf virus in minimum-till and conventional-till autumn-sown cereals. J. Agric. Sci. 148:407-419.

Kühne, T. 2009. Soil-borne viruses affecting cereals-Known for long but still a threat. Virus Res. 141:174-183.

Leitch, M. H., and Jenkins, P. D. 1995. Influence of nitrogen on the development of Septoria epidemics in winter. J. Agric. Sci. 124:361-368.

Lobell, D. B., Schlenker, W., and Costa-Roberts, J. 2011. Climate trends and global crop production since 1980. Science 333:616-620.

McDonald, B. A., and Linde, C. 2002. Pathogen population genetics, evolutionary potential, and durable resistance. Annu. Rev. Phytopathol. 40:349-379.

McElhany, P., Real, L., and Power, A. G. 1995. Vector preference and disease dynamics: A study of Barley yellow dwarf virus. Ecology 76:444-457.

McMullen, M., Bergstrom, G., De Wolf, E., Dill-Macky, R., Hershman, D., Shaner, G., and Van Sanford, D. 2012. A unified effort to fight an enemy of wheat and barley: Fusarium head blight. Plant Dis. 96:1712-1728.

McMullen, M. P., Jones, R., and Gallenberg, D. 1997. Scab of wheat and barley: A re-emerging disease of devastating impact. Plant Dis. 81:13401348.

Millennium Ecosystem Assessment. 2005. Ecosystems and Human Wellbeing: Synthesis. Island Press, Washington, D.C.

Mueller, N. D., Gerber, J. S., Johnston, M., Ray, D. K., Ramankutty, N., and Foley, J. A. 2012. Closing yield gaps through nutrient and water management. Nature 490:254-257.
Nielsen, L. K., Jensen, J. D., Nielsen, G. C., Jensen, J. E., Spliid, N. H., Thomsen, I. K., Justesen, A. F., Collinge, D. B., and Jørgensen, L. N. 2011. Fusarium head blight of cereals in Denmark: Species complex and related mycotoxins. Phytopathology 101:960-969.

O'Driscoll, A., Kildea, S., Doohan, F., Spink, J., and Mullins, E. 2014. The wheat-Septoria conflict: A new front opening up? Trends Plant Sci. 19:602-610.

Öborn, I., Bengtsson, J., Hedenus, F., Rydhmer, L., Stenström, M., Vrede, K., Westin, C., and Magnusson, U. 2013. Scenario development as a basis for formulating a research program on future agriculture: A methodological approach. Ambio 42:823-839.

Ordon, F., Habekuss, A., Kastirr, U., Rabensein, F., and Kühne, T. 2009. Virus resistance in cereals: Sources of resistance, genetics, and breeding. J. Phytopathol. 157:535-545.

Ortiz, R., Sayre, K. D., Govaerts, B., Gupta, R., Subbarao, G. V., Ban, T., Hodson, D., Dixon, J. M., Ortiz-Monasterio, J. I., and Reynolds, M. 2008. Climate change: Can wheat beat the heat? Agric. Ecosyst. Environ. 126:46-58.

Paillard, S., Treyer, S., and Dorin, B. (eds.) 2014. Agrimonde-Scenarios and Challenges for Feeding the World in 2050. Springer Science \& Business Media.

Parry, D. W., Jenkinson, P., and McLeod, L. 1995. Fusarium ear blight (scab) in small grain cereals-A review. Plant Pathol. 44:207-238.

Paul, P. A., Lipps, P. E., and Madden, L. V. 2005. Relationship between visual estimates of Fusarium head blight intensity and deoxynivalenol accumulation in harvested wheat grain: A meta-analysis. Phytopathology 95: 1225-1236.

Raaijmakers, J. M., Paulitz, T. C., Steinberg, C., Alabouvette, C., and Moënne-Loccoz, Y. 2009. The rhizosphere: A playground and battlefield for soilborne pathogens and beneficial microorganisms. Plant Soil 321: 341-361.

Rabbinge, R., and De Wit, C. T. 1989. Systems, models and simulation. Pages 3-15 in: Simulation and Systems Management in Crop Protection. R. Rabbinge, S. A. Ward, and H. H. Van Laar, eds. Pudoc, Wageningen.

Rabbinge, R., and Van Oijen, M. 1997. Scenario studies for future agriculture and crop protection. Eur. J. Plant Pathol. 103:197-201.

Roelfs, A. P., and Bushnell, W. R. (eds.) 1985. The Cereal Rusts. Vol. 2: The Diseases, Their Distribution, Epidemiology, and Control. Academic Press, Orlando, FL.

Rosenzweig, C., and Hillel, D. (eds.) 2015. Handbook of Climate Change and Agroecosystems: The Agricultural Model Intercomparison and Improvement Project (AgMIP) Integrated Crop and Economic Assessments. ICP Series on Climate Change Impacts, Adaptation, and Mitigation, Vol. 3. Imperial College Press,London.

Rosenzweig, C., and Parry, M. L. 1994. Potential impact of climate change on world food supply. Nature 367:133-138.

Rowe, W. D. 1980. Risk assessment approaches and methods. Pages 3-29 in: Society, Technology, and Risk Assessment. G. Conran, ed. Academic Press, New York.

Savary, S. 2014. The roots of crop health: cropping practices and disease management. Food Secur. 6:819-831.

Savary, S., Elazegui, F. A., and Teng, P. S. 1996. A Survey Portfolio for the Characterization of Rice Pest Constraints. IRRI Discussion Papers Series, 18. IRRI, Los Baños.

Savary, S., McRoberts, N., Esker, P. D., Willocquet, L., and Teng, P. S. 2017. Production situations as drivers of crop health: Evidence and implications. Plant Pathol. 66:867-876.

Savary, S., Nelson, A., Sparks, A. H., Willocquet, L., Duveiller, E., Mahuku, G., Forbes, G., Garrett, K. A., Hodson, D., Padgham, J., Pande, S., Sharma, M., Yuen, J., and Djurle, A. 2011. International agricultural research tackling the effects of global and climate changes on plant diseases in the developing world. Plant Dis. 95:1204-1216.

Savary, S., Nelson, A., Willocquet, L., Pangga, I., and Aunario, J. 2012. Modelling and mapping potential epidemics of rice diseases globally. Crop Prot. 34:6-17

Savary, S., Stetkiewicz, S., Brun, F., and Willocquet, L. 2015. Modelling and mapping potential epidemics of wheat diseases-Examples on leaf rust and Septoria tritici blotch using EPIWHEAT. Eur. J. Plant Pathol. 142:771-790.

Savary, S., Teng, P. S., Willocquet, L., and Nutter, F. W., Jr. 2006. Quantification and modelling of crop losses: A review of purposes. Annu. Rev. Phytopathol. 44:89-112.

Savary S., and Willocquet L. 2014. Simulation modeling in botanical epidemiology and crop loss analysis. APSnet Education Center. The Plant Health Instructor.

Savary, S., Willocquet, L., Elazegui, F. A., Teng, P. S., Van Du, P., Zhu, D., Tang, Q., Huang, S., Lin, X., Singh, H. M., and Srivastava, R. K. 2000. Rice pest constraints in tropical Asia: Characterization of injury profiles in relation to production situations. Plant Dis. 84:341-356.

Savary, S., and Zadoks, J. C. 1992. Analysis of crop loss in the multiple pathosystem groundnut-rust-late leaf spot. I. Six experiments. Crop Prot. 11:99-109. 
Schaafsma, A. W., Tamburic-Ilincic, L., and Hooker, D. C. 2005. Effect of previous crop, tillage, field size, adjacent crop, and sampling direction on airborne propagules of Gibberella zeae/Fusarium graminearum, Fusarium head blight severity, and deoxynivalenol accumulation in winter wheat. Can. J. Plant Pathol. 27:217-224.

Shiferaw, B., Smale, M., Braun, H. J., Duveiller, E., Reynolds, M., and Muricho, G. 2013. Crops that feed the world 10. Past successes and future challenges to the role played by wheat in global food security. Food Secur. 3:307-327.

Simón, M. R., Perelló, A. E., Cordo, C. A., Larrán, S., van der Putten, P. E., and Struik, P. C. 2005. Association between Septoria tritici blotch, plant height, and heading date in wheat. Agron. J. 97:1072-1081.

Singh, R. P., Singh, P. K., Rutkoski, J., Hodson, D. P., He, X., Jørgenssen, L. N., Hovmøller, M. S., and Huerta-Espino, J. 2016. disease impact on wheat yield potential and prospects of genetic control. Annu. Rev. Phytopathol. 54:303-322.

Siou, D., Gélisse, S., Laval, V., Repinçay, C., Canalès, R., Suffert, F., and Lannou, C. 2014. Effect of wheat spike infection timing on Fusarium head blight development and mycotoxin accumulation. Plant Pathol. 63:390-399.

Smale, M., Singh, R. P., Sayre, K., Pingali, P., Rajaram, S., and Dubin, H. J. 1998. Estimating the economic impact of breeding nonspecific resistance to leaf rust in modern bread wheats. Plant Dis. 82:1055-1061.

Smil, V. 2000. Feeding the World. A Challenge for the Twentieth Century. The MIT Press, Cambridge, MA.

Sommerhalder, R. J., McDonald, B. A., Mascher, F., and Zhan, J. 2010. Sexual recombinants make a significant contribution to epidemics caused by the wheat pathogen Phaeosphaeria nodorum. Phytopathology 100:855-862.

Suffert, F., and Sache, I. 2011. Relative importance of different types of inoculum to the establishment of Mycosphaerella graminicola in wheat crops in north-west Europe. Plant Pathol. 60:878-889.

Suffert, F., Sache, I., and Lannou, C. 2011. Early stages of Septoria tritici blotch epidemics of winter wheat: Build-up, overseasoning, and release of primary inoculum. Plant Pathol. 60:166-177.

Sundström, J. F., Albihn, A., Boqvist, S., Ljungvall, K., Marstorp, H., Martiin, C., Nyberg, K., Vågsholm, I., Yuen, J., and Magnusson, U. 2014. Future threats to agricultural food production posed by environmental degradation, climate change, and animal and plant diseases-A risk analysis in three economic and climate settings. Food Secur. 6:201-215.

Thresh, J. M. 1978. The epidemiology of plant virus diseases. In: Plant Disease Epidemiology. P. R.Scott and A. Bainbridge, eds. Oxford University Press, Blackwell.

Thresh, J. M. 1982. Cropping practices and virus spread. Annu. Rev. Phytopathol. 20:193-216.

Turmel, M. S., Speratti, A., Baudron, F., and Govaerts, B. 2015. Crop residue management and soil health: A systems analysis. Agric. Syst. 134:6-16.
United Nations. 2016. World Population Prospects: The 2015 Revision. United Nation, New York.

Van Der Fels-Klerx, H. J., Klemsdal, S., Hietaniemi, V., Lindblad, M., Ioannou-Kakouri, E., and Van Asselt, E. D. 2012. Mycotoxin contamination of cereal grain commodities in relation to climate in North West Europe. Food Addit. Contam. Part A 29:1581-1592.

Van Ittersum, M. K., and Rabbinge, R. 1997. Concepts in production ecology for analysis and quantification of agricultural input-output combinations. Field Crops Res. 52:197-208.

Willocquet, L., Aubertot, J. N., Lebard, S., Robert, C., Lannou, C., and Savary, S. 2008. Simulating multiple pest damage in varying winter wheat production situations. Field Crops Res. 107:12-28.

Willocquet, L., Elazegui, F. A., Castilla, N., Fernandez, L., Fischer, K. S., Peng, S. B. S., Teng, P. S., Srivastava, R. K., Singh, H. M., Zhu, D., and Savary, S. 2004. Research priorities for rice pest management in tropical Asia: A simulation analysis of yield losses and management efficiencies. Phytopathology 94:672-682.

Willocquet, L., Savary, S., Fernandez, L., Elazegui, F. A., Castilla, N., Zhu, D., Tang, Q., Huang, S., Lin, X., Singh, H. M., and Srivastava, R. K. 2002. Structure and validation of RICEPEST, a production situation-driven, crop growth model simulating rice yield response to multiple pest injuries for tropical Asia. Ecol. Modell. 153:247-268.

Willocquet, L., Savary, S., Fernandez, L., Elazegui, F. A., and Teng, P. S. 2000. Development and evaluation of a multiple-pest, production situation specific model to simulate yield losses of rice in tropical Asia. Ecol. Modell. 131:133-159.

Willyerd, K. T., Li, C., Madden, L. V., Bradley, C. A., Bergstrom, G. C., Sweets, L. E., McMullen, M., Ransom, J. K., Grybauskas, A., Osborne, L., Wegulo, S. N., Hershman, D. E., Wise, K., Bockus, W. W., Groth, D., Dill-Macky, R., Milus, E., Esker, P. D., Waxman, K. D., Adee, E. A., Ebelhar, S. E., Young, B. G., and Paul, P. A. 2012. Efficacy and stability of integrating fungicide and cultivar resistance to manage Fusarium head blight and deoxynivalenol in wheat. Plant Dis. 96:957-967.

World Health Organization. 2013. Research priorities for the environment, agriculture and infectious diseases of poverty. No. 976 in: World Health Organization Technical Report Series. World Health Organization, Geneva, Switzerland.

Xu, X. B. 2003. Effects of environmental conditions on the development of Fusarium ear blight. Eur. J. Plant Pathol. 109:683-689.

Yuen, J., and Mila, A. 2015. Landscape-scale disease risk quantification and prediction. Annu. Rev. Phytopathol. 53:471-484.

Zadoks, J. C. 2013. Crop Protection in Medieval Agriculture: Studies in PreModern Organic Agriculture. Sidestone Press, Leiden, Netherlands.

Zadoks, J. C., and Schein, R. D. 1979. Epidemiology and Plant Disease Management. Oxford University Press, New York. 